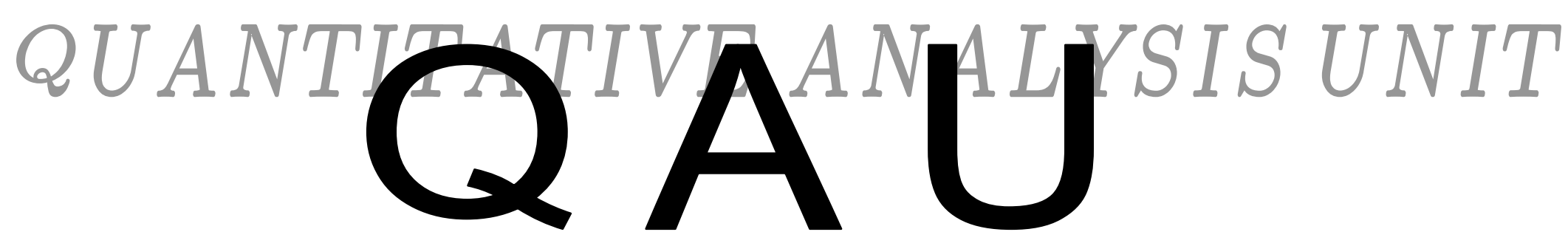

\title{
Bank Diversification, Market Structure and Bank Risk Taking: Theory and Evidence from U.S. Commercial Banks
}

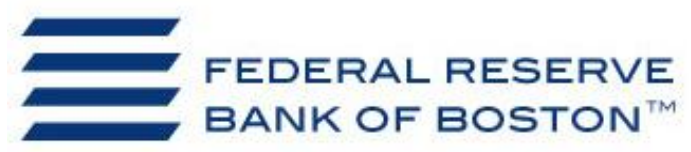

Working Paper No. QAU12-2
Martin Goetz

Federal Reserve Bank of Boston

This paper can be downloaded without charge from:

The Quantitative Analysis Unit of the Federal Reserve Bank of Boston

http://www.bostonfed.org/bankinfo/qau/index.htm 


\title{
Bank Diversification, Market Structure AND BANK Risk TAKing: THEORY AND EVIDENCE FROM U.S. COMMERCIAL BANKS
}

\author{
Martin Goetz * \\ January 17, 2012
}

\begin{abstract}
This paper studies how a bank's diversification affects its own risk taking behavior and the risk taking of competing, nondiversified banks. By combining theories of bank organization, market structure and risk taking, I show that greater geographic diversification of banks changes a bank's lending behavior and market interest rates, which also has ramifications for nondiversified competitors due to interactions in the banking market. Empirical results obtained from the U.S. commercial banking sector support this relationship as they indicate that a bank's risk taking is lower when its competitors have a more diversified branch network. By utilizing the state-specific timing of a removal of intrastate branching restrictions in two identification strategies, I further pin down a causal relationship between the diversification of competitors and a bank's risk taking behavior. These findings indicate that a bank's diversification also impacts the risk taking of competitors, even if these banks are not diversifying their activities.
\end{abstract}

JEL Classification: G21, G32, L22

Keywords: Risk Taking, Organization, Commercial Banks, Diversification, Competition

${ }^{*}$ Federal Reserve Bank of Boston, 600 Atlantic Avenue, Boston MA 02210. Email: Martin.Goetz@bos.frb.org. Tel.: (617) 9733018

Financial support from the Networks Financial Institute (Indiana State University) is greatly appreciated. I am very thankful to Ross Levine, Nicola Cetorelli, Marcia Millon Cornett, Ruben Durante, Tatiana Farina, Andy Foster, Juan Carlos Gozzi, Luc Laeven, Alex Levkov, Jose Liberti, Blaise Melly, Donald Morgan, and David VanHoose for helpful comments and discussions. I also thank seminar participants at, the Bank for International Settlements, Banque de France, Bentley College, Board of Governors, Brown University, European Business School, European Central Bank, Federal Reserve Bank of Boston, and Tilburg University for many comments and suggestions. The views expressed in this paper are solely those of the author and do not necessarily reflect official positions of the Federal Reserve Bank of Boston or the Federal Reserve System. 


\section{Introduction}

In this paper, I address one of the most basic questions in banking: are banks with lending activities in several banking markets safer than banks that focus their operations on a single market? Expanding lending operations into more markets allows banks to diversify risk across regions, and if loan returns across regions are not perfectly correlated, geographically diversified banks are safer because they are less exposed to shocks that hit individual areas (Diamond (1984); Demsetz and Strahan (1997); Morgan et al. (2004)). Banks' risk taking is also related to market structure, and risk taking could change because diversification across markets affects competition in banking markets. Competition for borrowers might intensify as banks expand their operations, which decreases a bank's rents, erodes its charter value, and therefore provides incentives for banks to take on more risk (Keeley (1990)). However, greater competition might also lead to lower loan rates, which reduces the extent of borrowers' risk shifting incentives and thus reduces a bank's exposure to risk of failure (Boyd and de Nicolo (2005)).

While many researchers examine the connection between bank diversification and risk taking, none consider how the interactions between banks that diversify and banks that focus their operations affect the fragility of these different banks. This omission turns out to be of first-order importance both conceptually and empirically. This paper provides more information on the relationship between bank diversification and risk taking by (1) explicitly modeling the interactions between banks that diversify geographically and those that focus their operations, and (2) providing empirical evidence from the U.S. banking sector, consistent with the model.

The model incorporates theories of market structure and risk taking (Boyd and de Nicolo (2005); Martinez-Miera and Repullo (2010)) and theories of bank structure and behavior (Stein (2002); Acharya et al. (2011)) to study the effect of banks' diversification on risk taking. By highlighting the relationship between bank man- 
ager and loan officers within banks, I show that loan officers have an incentive to shift lending towards certain borrower types when banks expand their branch network. Because of competition for borrowers, a shift in lending affects market loan interest rates and changes a bank's loan portfolio risk. This determines a bank's risk taking behavior. Furthermore, the shift in lending also impacts the behavior of competitors, which affects their exposure to risk of failure. Hence, the model shows that a bank's geographic diversification not only affects its own risk taking, but also shapes the risk taking behavior of other banks due to competition in the banking market. This model adds to the debate on diversification, market structure and risk taking by showing an additional channel that affects banks' risk taking.

I use information from the U.S. commercial banking sector to empirically examine the relationship between a bank's geographical diversification, the diversity of its competitors and the risk taking behavior of these different banks. By examining banks' level of geographic diversification across counties within a state, I find that a bank's risk taking is lower when its competitors have a more diversified branch network across counties. This finding is also robust to alternative measures of risk taking and diversification. While these results are consistent with the theoretical framework they do, however, not reflect a causal relationship since unobservable factors, such as bank efficiency, might exert an influence on a bank's risk taking behavior.

To estimate the causal impact of a bank's diversification on competing banks' risk taking, I employ two empirical strategies based on (1) the timing of intrastate branching deregulation and (2) a gravity model, which explains a bank's expansion behavior within a state (Goetz et al. (2011)). Because banks were not allowed to expand their branch network freely within state borders before the removal of these branching restrictions, I can identify the exogenous component of banks' expansion activity, as each identification strategy utilizes the state specific timing of a removal 
of intrastate branching restrictions to determine an exogenous change in banks' diversification. This allows me to pin down the causal effect of a bank's degree of diversification on its risk taking behavior and the risk taking behavior of competitors.

The first empirical strategy uses heterogeneity in the timing of intrastate branching deregulation across states as an instrument for the average bank's diversification within state borders. I find robust evidence that the failure risk of a bank decreases when competitors diversify across banking markets. Moreover, this effect is also economically significant: a bank's annual risk of failure decreases by approximately 20 $\%$ if competitors increase their geographic diversification by one standard deviation.

To further strengthen my results, I combine the timing of intrastate branching deregulation with a gravity model of bank expansion within a state in the second identification strategy to construct an instrumental variable at the bank level. ${ }^{1}$ By imbedding the timing of intrastate branching deregulation within a gravity model, I determine for each bank and year its projected level of diversity using this gravityderegulation model (Goetz et al. (2011)). In a second step, I then use this instrumental variable to estimate the effect of diversification on risk taking.

Because the gravity-deregulation model explains expansion at the bank level for each year, I can (1) account for a bank's endogenous decision to expand, and (2) capture unobservable state specific time-varying influences by including a set of state specific time fixed effects in the regression model. Using this identification strategy, I test whether the impact of a bank's expansion on its own risk of failure is different than the impact on competitors' risk taking, as highlighted by the model. Results from the gravity-deregulation model confirm the earlier findings and support the theorized link between a bank's diversification, its competitors' level of diversification and their risk taking behavior.

The main contribution of this paper is the theoretical and empirical identification

\footnotetext{
${ }^{1}$ I follow the methodology from Frankel and Romer (1999) who analyze whether and how international trade flows affect economic growth.
} 
of a direct effect of a bank's diversification on its own risk taking and the risk taking behavior of competitors. This adds to the debate on bank risk taking, market structure and bank organization, since my empirical results do not reject earlier theories and findings, but rather complement existing studies by identifying a further channel that affects bank risk taking. Although the theoretical framework incorporates findings on the relationship between bank organization and individual loan officers' behavior (Liberti and Mian (2009), Hertzberg et al. (2010)), I do not empirically assess the impact of a bank's organizational structure on individual loan officers' risk taking behavior within a bank. Moreover, I focus on the firm-wide effects of changes in a bank's diversification on its risk taking and the risk taking of competitors in this

paper. Furthermore, this paper is also related to studies of market structure and bank risk taking, based on regression results from cross-country analysis (de Nicolo (2000), Boyd et al. (2007)), and evidence from the Great Depression (Calomiris and Mason (2000), Mitchener (2005)).

The remainder of this paper is organized as follows: in Section 2, I provide a theoretical framework studying the relationship between a bank's level of diversification, the degree of competitors' diversification and their risk taking behavior. Following this, I present OLS regression results using information from U.S. commercial banks in Section 3. Empirical results on the causal relationship between diversification and risk taking is presented in Section 4. Section 5 concludes the paper.

\section{Theoretical Framework}

I build on Stein (2002) to show (1) how a bank's level of geographic diversification affects its risk taking and (2) the risk taking of competing banks. Stein (2002) and Berger et al. (2005) show that banks' organizational structure (decentraliza- 
tion versus hierarchy) determines their ability to produce and process information about borrowers. This has effects on banks' lending behavior as banks with a flatter organizational structure, and thus less diversification, are better at lending to soft information borrowers. The theoretical model is also related to theories highlighting the relationship between bank competition and lending relationships (Petersen and Rajan (1995), Dell'Ariccia and Marquez (2004)), and theories regarding the structure of banks and their behavior (Dell'Ariccia and Marquez (2010), Boot and Schmeits (2000)).

\section{$2.1 \quad$ Model}

Borrowers There is a mass of entrepreneurs with access to a risky technology which yields $R$ with probability $p(e)$. By increasing effort $e$ at cost $\frac{1}{2} e^{2}$, an entrepreneur's likelihood of success $p(e)$ increases. Moreover, an entrepreneur's likelihood of success is independent of other entrepreneurs' success probabilities. For any given level of effort, the success probability is less than one, and concave in effort with $p(0)=0.5$. Effort is unobservable and not verifiable to third parties. Entrepreneurs seek financing from banks, but differ in the level of collateral they can pledge when taking out a loan; some borrowers can pledge collateral $\lambda$ when taking out a loan. Since collateral $\lambda$ is observable and verfiable, borrowers with collateral are called "hard information" borrowers. Similarly, borrowers without collateral are referred to as "soft information" borrowers. In case a hard information borrower is not successful (with probability $1-p$ ), the bank receives that borrower's collateral $\lambda$. Given loan rate $r_{L}$, a borrower chooses $e$ to maximize his expected profit:

$$
\max _{e} E(\pi)= \begin{cases}p(e)\left[R-r_{L}\right]-(1-p(e)) \lambda-\frac{1}{2} e^{2} & \text { hard information } \\ p(e)\left[R-r_{L}\right]-\frac{1}{2} e^{2} & \text { soft information }\end{cases}
$$


Similar to Boyd and de Nicolo (2005), it can be shown that borrowers in this model shift risk towards banks when banks increase the loan rate. Entrepreneurs also differ in their unobservable outside option, denoted $\bar{\pi}$, which determines whether an entrepreneur will borrow or not. There is a continuum of borrowers in the market, defined by a continuous distribution of outside options with support $\mathbb{R}_{+}$. The measure of borrowers with an outside option of at most $\bar{\pi}$ is denoted as $F(\bar{\pi})$. For simplicity hard and soft information borrowers have different outside options, e.g. $\bar{\pi}^{S}=\bar{\pi}^{H}+\lambda .^{2}$ An entrepreneur takes out a loan at rate $r_{L}$ if his expected profit is greater or equal than his outside option. The measure of borrowers at loan rate $r_{L}$ is denoted $F\left(\pi\left(r_{L}\right)\right.$ ), which yields loan demand $D$ (Martinez-Miera and Repullo $(2010))$ :

$$
D\left(r_{L}\right)=F\left(\pi\left(r_{L}\right)\right)
$$

Loan demand is decreasing in the loan interest rate $r_{L}, D^{\prime}\left(r_{L}\right)=F^{\prime}\left(\pi\left(r_{L}\right)\right) \pi^{\prime}\left(r_{L}\right)<$ 0 . Inverse loan demand is denoted by $r_{L}(D)$ with $r_{L}^{\prime}(D)<0$.

Banks Banks differ in their organizational structure which is characterized by a bank's number of branches. The number of branches also determines the number of distinct banking markets a bank is active in, and thus reflects its level of geographic diversification. Each branch consists of a loan officer that decides on lending, and branches of the same bank do not compete for borrowers within the same market. Further, each bank also consists of a CEO (see below).

Loan officers make lending decision in bank branches. Their lending decision is shaped by (a) competition in the market for borrowers (horizontal competition), and (b) the possibility to become the next CEO (Acharya et al. (2011)) (vertical competition). Because borrower types are observable, loan officers face a loan demand $D_{S} / D_{H}$ for soft/hard information borrowers. Moreover, loan officers in a market

\footnotetext{
${ }^{2}$ This ensures that the measure of borrowers demanding loans at a given level of outside option is not affected by the availability of collateral.
} 
compete for borrowers a la Cournot and each loan officer has one unit of funding available, which he allocates between soft and hard information borrowers. Suppose the total supply of credit to hard information borrowers in a market is denoted by $A .^{3}$ Expected profits from lending to hard/soft information borrowers are given as $\mu_{H} / \mu_{S}:$

$$
\begin{aligned}
\mu_{H} & =p_{H}(A)\left(1+r_{H}(A)\right)+\left(1-p_{H}(A)\right) \lambda \\
\mu_{S} & =p_{S}(A)\left(1+r_{S}(A)\right)
\end{aligned}
$$

Loan officers choose a loan portfolio $\beta$ (= share of loans to hard information borrowers) to maximize their expected profit.

A bank's CEO receives a fraction $\gamma$ of every branch's expected profit, and his only role is evaluating every loan officer to determine his successor. In particular, he observes each loan officers profit at $\operatorname{cost} c$ - where $c$ is decreasing in a loan officer's choice of $\beta^{4}$ - and chooses the loan officer with the highest profit net of the evaluation cost to be the next CEO. ${ }^{5}$

\section{Horizontal Competition (within markets) Each loan officer in a market chooses}

to lend a fraction of its funding to hard information borrowers in that market. For simplicity, suppose there are two branches of competing banks in that market. Let the fraction of lending by loan officer $a$ be denoted by $\alpha$, and the fraction of loan officer $b$ by $\beta$. Total lending to hard information borrowers in this market is then $A=\alpha+\beta$. Expected profits for loan officer $b$ is therefore given as: $E(\pi)=\left[\beta \mu_{H}(A)+(1-\beta) \mu_{S}(A)\right] \times(1-\gamma)$.

\footnotetext{
${ }^{3}$ Because the total amount of credit within a market is limited by the number of branches, expected profits from lending to soft information borrowers are also determined by $A$.

${ }^{4}$ The rationale is that it is less costly for the CEO to evaluate a loan portfolio of hard information borrowers.

${ }^{5} \mathrm{~A}$ loan officer's choice of $\beta$ also affects his chance of becoming the next CEO. If a bank has only one branch, the loan officer will become the next CEO with certainty. However, loan officers in banks with more than one branch compete with each other to become the next CEO.
} 
Vertical Competition (within banks) Suppose a bank has two branches, and let loan officers in the branches of this bank be labeled $i$ and $j$. Each loan officer chooses a fraction $\beta_{i}, \beta_{j}$ of lending to hard information borrowers in his respective banking market. Loan officer $i$ will become the next CEO if his profit net of evaluation cost $\left(\pi_{i}-c_{i}\right)$ are larger than $j$ 's net profit $\left(\pi_{j}-c_{j}\right)$. Because evaluation costs are decreasing in the loan officer's share of hard information borrowers, the probability of becoming the next CEO for loan officer $i\left(p r_{i}\right)$ increases in $\beta_{i}$ (see appendix for details). ${ }^{6}$

\subsection{Equilibrium and Comparative Statics}

\subsubsection{Equilibrium}

In equilibrium, banks discriminate between hard and soft information borrowers, and offer a separate interest rate for each borrower type. Denote the CEO's equilibrium net profit from each branch as $\Pi$, and suppose there are two branches $(i, j)$. Loan officer $i$ then chooses $\beta_{i}$ to maximize:

$$
\max _{\beta_{i}}(1-\gamma) E\left(\pi_{i}\left(\beta_{i}\right)\right)+p r_{i}\left(\beta_{i}, \beta_{j}\right) \times 2 \frac{\gamma}{1+\rho}[\bar{\Pi}]
$$

Since loan demand is increasing in interest rates, there is an optimal allocation of lending between soft and hard information borrowers.

\subsubsection{Comparative Statics}

Competition within a market For simplicity, I focus on the case of two banks and two branches. Let the choice of loan officers' share of hard information loans in different banks be denoted by $\alpha$ and $\beta$, and the share of loan officers of the same bank be denoted by $\beta_{i}$ and $\beta_{j}$. Because loan officers within a market compete for

\footnotetext{
${ }^{6}$ This is similar to a result from first priced sealed bid auctions.
} 
borrowers a la Cournot, loan officers have an incentive to differentiate themselves from each other:

Proposition 1 (Differentiation) A loan officer's share of hard information borrowers is negatively related to its competitor's choice of hard information borrowers.

Suppose a competing branch increases lending to hard information borrowers. Because total credit supply in a banking market is limited and loan officers compete for borrowers a la Cournot, interest rates for hard information borrowers decrease, while interest rates for soft information borrowers increase. This makes lending to soft information borrowers more profitable, which induces a loan officer to increase lending to soft information borrowers.

Competition within banks It can be shown that loan officers in banks with more branches will choose a loan portfolio with a larger share of hard information borrowers.

Proposition 2 (Effect of hierarchy on $\beta$ ) A loan officer in a bank with more branches chooses a larger $\beta$ than a loan officer in a bank with less branches.

This result is similar to Stein (2002). While Stein (2002) shows that internal capital markets in more hierarchical banks lead to a larger share of hard information borrowers, the mechanism here is the tournament between loan officers for the bank's CEO position (Acharya et al. (2011)).

\subsection{Risk}

\subsubsection{Loan Portfolio Risk}

In equilibrium, branches lend to a continuum of soft and hard information borrowers. Repayment by each borrower is stochastic and independent within and across 
borrower types. Further, due to symmetry, each borrower type chooses the same level of effort and exhibits the same repayment probability. Suppose, a bank's loan portfolio consists of infinitely granular soft and hard information borrowers and is given by $X$. Because profit from lending to a borrower type is binomially distributed, $X$ can be approximated by a normal distribution with mean $\mu_{B}$ and variance $\sigma_{B}^{2}$, where

$$
\begin{aligned}
\mu_{B} & =\beta \mu_{H}+(1-\beta) \mu_{S} \\
\sigma_{B}^{2} & =\beta^{2} \sigma_{H}^{2}+(1-\beta)^{2} \sigma_{S}^{2},
\end{aligned}
$$

$\sigma_{H}^{2}$ and $\sigma_{S}^{2}$ is the variance of hard and soft information borrowers, respectively.

\subsubsection{Risk Taking}

For simplicity, a bank holds no capital, and so it is bankrupt if the realization of its loan return is negative. A bank's probability of default $(P D)$ is therefore given as:

$$
P D=\operatorname{Pr}(X<0)=\operatorname{Pr}\left(Z<-\frac{\mu_{B}}{\sigma_{B}}\right)=\Phi\left(-\frac{\mu_{B}}{\sigma_{B}}\right), \quad \text { with } Z \equiv \frac{X-\mu_{B}}{\sigma_{B}}
$$

Note that $Z$ follows a standard normal distribution.

\section{Proposition 3 (Change in Loan Portfolio and Probability of Default)}

Depending on the initial share of hard information borrowers, an increase in lending to hard information borrowers can either increase or decrease a bank's probability of default.

Consider again the case of two competing loan officers in two different banks where the loan officer's choice of lending to hard information borrowers is denoted by $\alpha / \beta$. A loan officer's change of $\beta$ has two effects. On the one hand, it directly affects the variance and expected value of a bank's loan portfolio. However, it also 
leads to a response by competing loan officers (Proposition 1):

$$
\frac{\partial P D}{\partial \beta} \propto \frac{\partial \sigma_{B}}{\partial \beta}\left(1+\frac{\partial \alpha}{\partial \beta}\right)
$$

An increase in $\beta$ lowers loan rates to hard information borrowers which lowers the variance of loans to hard information borrowers $\left(\sigma_{H}^{2}\right)$. However, this increase also augments the variance of loans to soft information borrowers $\left(\sigma_{S}^{2}\right)$. Because $\sigma_{S}^{2}$ $\left(\sigma_{H}^{2}\right)$ is concave and increasing (convex and decreasing) in $\beta$, the marginal increase in $\sigma_{S}^{2}$ is larger than the marginal decrease in $\sigma_{H}^{2}$ if $\beta$ is small. Hence, a bank's $P D$ increases when banks increase their share of loans to hard information borrowers.

Because of competition for borrowers in the market, competing loan officers respond to changes in $\beta$ by also changing their loan portfolio (Proposition 1). This response alters the impact of changes in a bank's loan portfolio on a bank's risk. Depending on parameter values, the overall effect can also be inverted. ${ }^{7}$

\subsection{Diversification, Risk Taking and Competitor's Risk Tak- ing}

The model argues that a bank expansion intensifies agency problems within the bank which then leads to a shift in lending toward hard information borrowers. This is similar to Stein (2002). By considering competition for borrowers in the market, the model also shows that competing banks will react to this shift in lending by increasing lending to soft information borrowers. So, the diversification of one bank leads to a specialization of lending to certain borrowers by both banks.

Since loan returns are stochastic, the model further shows that a bank's diversification directly impacts the bank's risk taking as it changes the bank's exposure to risk of failure. This effect can be positive or negative, and depends on (a) the initial

\footnotetext{
${ }^{7}$ This happens if the elasticity of lending to hard information borrowers across loan officers is less than -1 .
} 
level of a bank's loan portfolio, and (b) the response of competitors in the banking market. Aside from this effect, a bank's diversification activity also affects the risk taking of competitors, even if they are not changing their level of diversification, which happens because of the specialization on certain borrowers by competitors.

The theoretical framework shows that these effects can be positive or negative. Therefore, I examine this relationship empirically using information from the U.S. banking sector in the next section.

\section{Diversification and Risk Taking}

\subsection{Empirical Strategy}

In the empirical analysis I focus on differences in the level of geographic diversification between banks and their competitors. Thus, I first determine for each bank in a banking market its level of geographic diversification, $D_{i, t}$. Averaging this value within a banking market and excluding bank $i$ from that calculation, allows me to measure the average level of geographic diversity for bank $i$ 's competitors $\left(D_{-i, t}\right)$. Subtracting these two values from each other $\left(\bar{D}_{i, t}=D_{-i, t}-D_{i, t}\right)$ then yields the difference in the degree of diversification between bank $i$ and its competitors. To determine the relationship between this variable and bank $i$ 's risk taking, I estimate the following regression:

$$
R_{i, t}=\alpha_{i}+\alpha_{t}+\beta \bar{D}_{i, t}+\mathbf{X}_{i, s, t}^{\prime} \rho+\varepsilon_{i, t}
$$

where $R_{i, t}$ is a measure of risk taking for bank $i$ at time $t ; \bar{D}_{i}$ reflects differences in the level of diversification between bank $i$ and its competitors; $\mathbf{X}_{i, s, t}$ is a vector of bank-, and or state-specific control variables; $\alpha_{i} / \alpha_{t}$ are bank and time fixed effects.

The coefficient of interest is $\beta$ : a positive value of $\beta$ suggests that a bank's risk taking 
increases as it becomes more diversified than its competitors. Similarly, a negative value suggests that a bank's risk taking decreases as its competitors increase their relative level of geographic diversity.

\subsection{Data}

\subsubsection{Sources}

I use accounting data from commercial banks in the United States. These data come from Reports of Condition and Income data ('Call Reports'), which all banking institutions regulated by the Federal Deposit Insurance Corporation (FDIC), the Federal Reserve, or the Office of the Comptroller of the Currency need to file on a regular basis. I use semiannual data from the years 1976 to 2007 and only consider commercial banks in the 50 states of the U.S. and the District of Columbia. The geographical location of bank branches is recorded in the 'Summary of Deposits' which contains deposit data for branches and offices of all FDIC-insured institutions. Aggregate state and county level data are from the Bureau of Economic Analysis.

\subsubsection{Variable Definitions}

Risk Taking Related to the theoretical model, I measure a bank's probability of default by Inverse Z-Score. Assuming that bank profits are normally distributed (Roy (1952)), a bank's probability of default can thus be approximated by (Laeven and Levine (2009), and Jimenez et al. (2010)):

$$
\text { Inverse Z-Score }=\frac{\text { Standard Deviation of Return on Assets }(\text { ROA })}{\text { ROA }+ \text { Capital-Asset-Ratio }}
$$

Z-Score can be interpreted as the number of standard deviations profit can fall before a bank is bankrupt. Hence, Inverse Z-Score is a risk measure, where higher values indicate greater bankruptcy risk. I use a five semi-annual moving average to 
estimate the volatility of profits using balance sheet information. To net out possible time trends in return on assets (ROA) over the sample period, I subtract ROA from its annual average. ${ }^{8}$ In addition to this variable, I construct a Distress indicator which takes on the value of one whether a bank's capital-asset ratio drops by more than $1 \%$ point in two consecutive years (Boyd et al. (2009)). ${ }^{9}$ Aside from this, I also use balance sheet information and follow Laeven et al. (2002) to construct a 'CAMEL' rating for each bank and year. ${ }^{10}$ U.S. bank regulators evaluate the stability of banks using balance sheet information and on-site inspections, and combine their assessment in 'CAMEL' ratings, which range from 1 to 5, with higher ratings indicating weaker banks. Because 'CAMEL' ratings are not publicly available, I follow the methodology of Laeven et al. (2002) to construct them using balance sheet information only.

Diversification I consider a U.S. county to be a relevant banking market for commercial banks (Berger and Hannan (1989)), and hence I focus on banks' expansion into other counties within the same state. Morover, I do not focus on a bank's expansion within the same banking market, i.e. the opening of new branches in the same county, and capture a bank's structure across markets for each year by two variables. The first variable is a Herfindahl Index of deposit concentration across markets by summing up the squared share of deposits a bank has in each market. This Herfindahl Index takes on values between zero and one, where larger values indicate that a bank has a flatter organizational structure as it focuses on fewer markets. I subtract this Herfindahl Index from one, so that smaller values of this variable indicate a less diversified bank. Second, I compute for each bank and year

\footnotetext{
${ }^{8}$ This is equivalent to first estimating a year fixed regression of ROA, and then using the residuals of ROA to compute Inverse Z-Score. The following OLS and 2SLS results also hold if I use reported ROA to determine Inverse Z-Score.

${ }^{9} \mathrm{I}$ use the $1 \%$ point threshold because it is the 10th percentile of the annual change in capitalasset ratio in my sample.

${ }^{10} \mathrm{CAMEL}$ stands for Capital adequacy, Asset quality, Management quality, Earnings and Liquidity
} 
the natural logarithm of banking markets, where I simply count the number of counties a bank has branches in. Lower values imply less geographic diversification as they reflect that a bank is active in fewer markets.

For each bank and year, I determine the average of these two variables of all banks that are active in the same market. Then, I take the average of each measure in a county without including bank $i$ and assign it to bank $i$, which yields for each bank an average measure of bank $i$ 's competitors' diversification. Finally I subtract a bank $i$ 's measure of diversification from the average competitor's degree to compute $\bar{D}_{i, t}$ (see equation (3)). This variable then captures relative differences between the diversification of bank $i$ and its competitors, where higher values indicate that the competitors of bank $i$ are relatively more diversified than bank $i$.

Controls To account for bank specific effects, I include the ratio of total loans to total assets, the log of total assets, a dummy variable indicating whether the bank is part of a bank holding company, and the capital-asset-ratio as control variables. These variables are computed from balance sheet information for every bank and year. State specific business cycle fluctuations are captured by the annual growth of state personal income as well as a lag thereof. Since local banking market conditions changed over the sample period, I include the log number of branches in a market, $\log$ number of banks in market, the concentration of deposits across banks in a market (Herfindahl Index) and population per branch in a market to account for this.

\subsubsection{Sample Characteristics}

The U.S. banking sector also consists of several large banks that are active in more than one state. The risk taking behavior of these banks is supposed to be different than the behavior of banks that operate branches within state borders. Since I 
am interested in the relationship between diversification and local competition, I exclude banks that are active in more than one state. Additional details regarding the construction of variables and the sample are given in the appendix.

The sample consists of 17,331 banks and spans the years 1977 to 2006. The average bank size is $\$ 275$ million, reflecting the fact that the U.S. banking sector consists of many small banks and a few larger institutions. While the average return on assets for banks in the sample is $0.57 \%$, banks are well capitalized with an average capital-asset ratio of $9.23 \%$. Differences between diversified and nondiversified banks are shown in Table 1 . The majority of bank-year observations (about 83 $\%$ are from nondiversified banks. This also reflects the fact that only $6 \%$ of all banks were diversified in 1977, whereas almost half of all banks in 2006 had at least branches in two counties. Moreover, Table 1 suggests that diversified banks tend to be (a) less risky, (b) larger, and (c) have lower capital-asset ratios.

\subsection{Results}

All regression models include bank fixed effects, which implies that the estimated coefficient represents within bank changes in their risk taking behavior as a bank's competitors' become more diversified than banks. Standard errors are robust and clustered at the bank level. Results are presented in Table 2 and indicate that a bank's risk taking is negatively related to differences in the diversification of bank $i$ and its competitors even without conditioning on bank or macroeconomic controls. ${ }^{11}$ Moreover, the effect is significant at the $1 \%$ level and robust to the inclusion of bank and macroeconomic controls (column 2 and 3 ). The first two regression models include year fixed effects to account for unobservable time trends. However, these fixed effects only capture unobservable time-varying effects at the country level. Therefore I include region specific (column 4) or state-specific time dummies (col-

\footnotetext{
${ }^{11}$ Since Inverse Z-Score is small, I multiply it by 1,000 for my analysis.
} 
umn 5) to capture unobservable time-varying effects on banks' risk taking at the region or state level. ${ }^{12}$ In particular, the state-specific time dummies capture unobservable effects such as changes in the competitive environment of commercial banks at the state level. The relationship between banks' diversification and risk taking is significant at the $1 \%$ level in all regression models.

To examine whether the results are sensitive to the definition of risk taking, I repeat the analysis using the Distress Indicator or 'CAMEL' ratings as dependent variable. I also include state-year fixed effects to account for unobservable characteristics that vary within a state. Regression results are presented in Table 3 and confirm the earlier findings as the results suggest that a bank's risk taking is lower when competitors become more diversified. Several banks exit the sample due to mergers and acquisitions or failures. Although I include bank fixed effects in the analysis, it is possible that a weeding out of risky banks (Carlson and Mitchener (2009)) affects my findings. Therefore, I estimate the relationship between risk taking and diversification excluding all banks that fail, merge or become acquired during the sample period. The earlier findings are not driven by this and are robust to this sample restriction. Similarly, banks also engage in mergers and acquisitions during the sample period. This also affects the regression results. Specifically the measure of risk taking, Inverse Z-Score, is affected as a merger or acquisition leads to a re-evaluation of banks' balance sheets. Therefore, I exclude observations one year before to one year after a bank's merger and/or acquisition (column 4), or all observations after a bank engages in a merger or acquisition (column 5). While the significance level drops, my earlier conclusions are not entirely driven by this. Due to construction, Inverse Z-Score is correlated over time, as I use a five semester moving average to estimate the volatility of bank profits. Hence, Inverse Z-Score in

\footnotetext{
${ }^{12}$ The regions are Midwest (IA, IL, IN, KS, MI, MN, MO, ND, NE, OH, WI), Northeast (CT, MA, MD, ME , NH, NJ, NY, PA, RI, VT, WV), South (AL, AR, DC, FL, GA, KY, LA, MS, NC, OK, SC, TN, TX, VA) and West (AZ, CA, CO, ID, MT, NM, NV, OR, UT, WA, WY).
} 
year $t$ uses information on profits that are also used for the computation of Inverse Z-Score in year $t-1$. Aside from this, persistence in earnings might also contribute to a potential serial correlation of my risk measure. To address this, and virtually eliminate all autocorrelation due to construction, I restrict the sample and only include every third year in the estimation in column 6 . The estimated coefficient increases in magnitude and significance, suggesting that autocorrelation biases the coefficient towards zero. Overall, these findings suggest that the relationship between diversification and risk taking is not driven by a bank's merger activity or the measurement of risk taking and diversification.

To translate these findings into a likelihood of failing, I estimate how a bank's probability of failing is related to Inverse Z-Score. Using information on the bankruptcy of 1,152 bank failures during the sample period, I estimate a state and year fixed effects logit regression and compute the average marginal effect of a one unit change in Inverse Z-Score on a bank's failure likelihood. ${ }^{13}$ Estimations from this logit model suggest that a one unit increase in Inverse Z-score decreases the likelihood of failing by approximately $1.2 \%$-points. Using the coefficient from column 4 in Table 2 , I find that if the difference between a bank's competitors' diversification and the diversity of a bank increases by one standard deviation, then the probability of failure for a bank decreases by 0.6 basis points. During the sample period, on average three out of a thousand banks fail each year, and so this implies that the average annual failure rate would be reduced by approximately $2 \%$. This is a rather small effect. However, it is a net effect and does not reflect the causal impact of diversification on risk taking since causality is not identified in this Ordinary-least squares estimation.

\footnotetext{
${ }^{13}$ Because it is not possible to compute Inverse Z-Score in the last year of a bank's existence, I determine for each bank whether it fails or not in the last period when Inverse Z-Score is available.
} 


\subsubsection{Dynamic effects}

In 1977 about $5 \%$ of all banks in the sample have branches in more than one county. In 2006, on the other hand, almost every second bank has a branch network that spans at least two counties. To examine the dynamic effects of risk taking as competitors expand, I estimate the following regression model:

$$
R_{i, t}=\alpha_{i}+\alpha_{t}+\sum_{p=-10}^{10} \beta_{p} Y_{p, t}+\mathbf{X}_{i, s, t} \rho+\varepsilon_{i, t}
$$

where $R_{i, t}$ is the Inverse Z-Score of bank $i$ in year $t, Y_{p, t}$ is a dummy variable that takes on the value of one if in year $t$, bank $i$ 's competitors diversify their branch network across markets in $p$ years. The effect on risk taking in the year of the competitors' expansion is dropped due to collinearity. Thus the coefficients $\beta_{p}$ are relative to the year of competitors' expansion. Figure 1 plots the estimated coefficients $\beta_{p}$ as well as the $95 \%$ confidence interval for these coefficients. To account for a bank's own diversification activity I restrict attention to banks that are only active in a single market.

Figure 1 shows that a bank's risk taking decreases once its competitors expand their branch network into more markets. Furthermore, the figure shows that risk taking does not significantly change before a competitor expands, and only decreases significantly two years after a competitors expansion. This lagged response can partly be attributed to the fact that Inverse Z-Score is smoothed as it is computed using information from earlier years. The pattern in Figure 1 also shows that a bank's risk taking stays significantly lower once competitors diversified their branch network into more markets, suggesting that the expansion of competitors has an effect on a bank's risk taking behavior. 


\subsubsection{Own Diversification vs. Competitors' Diversification}

The results so far examine how bank risk taking is related to changes in the relative difference in geographic diversification of a bank and its competitors. It is also possible to differentiate this effect further. In particular, I examine whether this effect is different if (a) a bank is more diversified than its competitors, or (b) a bank is less than diversified than its competitors. Therefore, I estimate the following regression model:

$$
R_{i, t}=\alpha_{i}+\alpha_{t}+\sum_{e=1}^{e=3} \beta_{e} O_{i, e, t}+\sum_{e=1}^{e=3} \gamma_{e} C_{i, e, t}+\mathbf{X}_{i, t}{ }_{i, t}+\varepsilon_{i, s, t}
$$

where $R_{i, t}$ is the Inverse Z-Score of bank $i$ in year $t, O_{i, e}\left(C_{i, e t}\right)$ is a dummy variable that takes on the value of one if the relative difference in diversification between bank $i$ and its competitor is positive (negative), and in the highest, medium or lowest sample tercile compared to the case where a bank and its competitors are not diversified. For example, $\beta_{3}$ reflects the difference in risk taking if bank $i$ is more diversified than its competitors and the diversification difference is in the highest sample tercile. Similarly, $\gamma_{3}$ captures the difference in risk taking if bank $i$ 's competitors are more diversified that bank $i$ and this difference is in the highest sample tercile. The estimated coefficients are plotted in Figures 2(a) and 2(b), and show that a bank's risk taking is lower when it is less diversified than its competitors, but is higher when it is more diversified than its competitors. Interestingly, this effect changes sign when both banks are equally diversified. 


\section{The Effect of Diversification on Risk Taking: 2SLS}

Ordinary-least squares estimation does not allow an identification of the causal relationship between the effects of diversification on risk because of, for instance, influences that jointly affect bank risk taking and diversification. To address this concern, I employ two instrumental variable strategies. The first strategy uses the timing of intrastate branching deregulation at the state level as an excluded instrument for the diversification activity of banks. The second approach combines the timing of intrastate branching deregulation and bank specific characteristics in a gravity-deregulation model similar to Frankel and Romer (1999) to develop an instrumental variable at the bank level.

\subsection{Intrastate Branching Deregulation as a Natural Exper- iment}

Banks in the United States were restricted in their branching decision within and across states for many decades. Limits on the location of branch offices were imposed in the 19th century, and were supported by the argument that allowing banks to expand freely could lead to a monopolistic banking system. The granting of bank charters was also a profitable income source for states, increasing incentives for states to enact regulatory policies. ${ }^{14}$ These regulations led to a banking system that was characterized by local monopolies within states since geographical restrictions prohibited other banks from entering a market. Because banks were beneficiaries of this regulation, they also had an incentive to preserve the status quo (Kroszner and Strahan, 1999).

\footnotetext{
${ }^{14}$ How severe these restrictions were shows the case of Illinois: before the removal of these restrictions, the state allowed banks to only open two branches within 3,500 yards of its main office (Amel and Liang, 1992).
} 
With the emergence of new technologies - such as the Automated Teller Machines and more advanced credit scoring techniques - banks' benefits from regulation declined. Eventually intrastate branching restrictions were lifted in states, and banks were allowed to branch freely within a state. The passage of the Riegle-Neal Act in 1994 by U.S. Congress finally removed all remaining barriers by the middle of the 1990s. ${ }^{15}$

The first stage regression model is given as:

$$
\bar{D}_{i, t}=\alpha_{i}+\alpha_{t}+\gamma Z_{i, s, t}+\mathbf{X}_{i, s, t}^{\prime} \rho+\varepsilon_{i, t},
$$

where $\bar{D}_{i, t}$ is the relative level of geographic diversity between bank $i$ and its competitors, and larger values of $\bar{D}_{i, t}$ indicate that competing banks are more diversified than bank $i ; Z_{i, s, t}$ is an instrumental variable, based on (1) the timing of intrastate branching deregulation, or on (2) a gravity-deregulation model; $\mathbf{X}_{i, s, t}$ is a vector of bank-, and or state-specific control variables; $\alpha_{i} / \alpha_{t}$ are bank and time fixed effects.

In the second stage, I use the predicted value of $\bar{D}_{i, t}$ to determine how it impacts a banks' risk taking.

$$
R_{i, t}=\beta \hat{\bar{D}}_{i, t}+\mathbf{X}_{i, s, t}^{\prime} \gamma+\tilde{\delta}_{i}+\tilde{\delta}_{t}+\eta_{i, s, t}
$$

where $\hat{\bar{D}}_{i, t}$ is the predicted value of the relative level of diversification between a bank and its competitors from the first stage regression. I use the same data sources as in the earlier analysis. Following previous research on intrastate branching deregulation, I drop Delaware and South Dakota from the analysis since the structure of the banking system in these states was heavily affected by other laws. Therefore it is not possible to isolate the effect of intrastate branching deregulation in these two

\footnotetext{
${ }^{15}$ Previous research on intrastate branching deregulation suggests that the removal of branching restrictions had significant effects on the real activity and economic development. See among others Jayaratne and Strahan, 1996, Beck et al., 2010. Dates for each state are given in Table B.II.
} 
states.

\subsection{State-level instruments}

\subsubsection{Intrastate Branching Deregulation and Diversification}

Intrastate branching restrictions prohibited banks from expanding their branch network for many years. Figure 3 shows the dynamic effects of intrastate branching deregulation in a state on the log number of markets a bank is active in. In particular, I estimate the following regression model:

$$
\ln \left(M_{i, t}\right)=\alpha_{i}+\alpha_{t}+\sum_{p=-10}^{15} \beta_{p} Y_{p, s, t}+\varepsilon_{i, t}
$$

where $\ln \left(M_{i, t}\right)$ is the $\log$ number of banking markets bank $i$ is active in during year $t, Y_{p, s, t}$ is a dummy variable that takes on the value of one if in year $t$, state $s$ liberalizes its intrastate branching restriction in $p$ years. The effect on diversification in the year of deregulation $Y_{0, s, t}$ is dropped due to collinearity; the coefficients $\beta_{p}$ are relative to the year of intrastate branching deregulation. Figure 3 plots the estimated coefficients $\beta_{p}$ as well as the $95 \%$ confidence interval for these coefficients. The figure indicates that, following the removal of branching restrictions, banks continuously expand their branch network into more counties. Furthermore, a bank's expansion tendency is stronger in earlier years following intrastate branching deregulation, and then slows down.

The instrumental variables for the 2SLS analysis are motivated by this finding, and are based on the following four sets of time-varying, state-level instruments. First, I use a dummy variable taking on the value of one once a state liberalized its branching restrictions, and zero otherwise. While this indicator captures the average effect of intrastate branching deregulation on a bank's geographic diversification, it does not capture changes over time. Therefore, I also use the number of years since a 
state first started to remove its intrastate branching restrictions, and a square term to allow for a quadratic relationship. ${ }^{16}$ Third, I employ a nonparametric specification that includes independent dummy variables for each year since a state removed its branching restrictions, taking a value of one all the way through the first ten years after deregulation, and zero otherwise. Lastly, I use the natural logarithm of one plus the number of years since a state removed its intrastate branching restrictions.

To isolate the effect of bank's own expansion activity during the sample period, I restrict attention to observations where banks are not diversified and therefore only operate branches in one county. $\hat{\bar{D}}_{i, t}$ is thus measured relative to a nondiversified bank $i$ and thus captures the diversification activity of bank $i$ 's competitors. Furthermore, I exclude observations one year before and after a bank's merger or acquisition to account for changes in my risk measure due to merger activity. First stage regression results of these instruments on competitors' expansion across markets are presented in Panel B of Table 4. Similar to Figure 3, results in Table 4 indicate that intrastate branching deregulation is associated with an increase in the diversification of banks as measured by the Herfindahl Index of deposits across banking markets (columns 1 to 4 ). This also holds when I measure a bank's diversification using the log number of markets a bank is active in (columns 5 to 8 ). The associated F-statistics support the use of these instruments as F-test results show that intrastate branching deregulation significantly impacts the expansion of banks.

\subsubsection{Diversification and Risk Taking: Second-stage}

As mentioned before, I restrict attention to banks that are not geographically diversified and also exclude observations around the year when banks engage in a merger and/or acquisition. Hence, the measure of relative diversification reflects changes in a competitors degree of geographic diversity. Panel A of Table 4 reports second

\footnotetext{
${ }^{16}$ Since Figure 3 shows that banks' expansion decreases over time, I only allow for a linear and quadratic trend up to ten years after deregulation.
} 
stage results of a 2SLS regression of bank risk on the level of geographic diversification of competing banks, as measured by the competitor's average dispersion across markets (columns 1 to 4 ), or the average number of markets competitors are active in (columns 5 to 8$)$.

The results indicate that bank risk decreases significantly when competitors expand their diversification across markets. This effect is not sensitive to the definition of banks' diversification, since I also find a statistically significant relationship between competitors' diversification and risk when I use the number of markets, competitors are active in (columns 5 to 8 ). Moreover, I also find that the effect between competitors' diversification and risk taking is not sensitive to the definition of risk since I find a statistically significant relationship between risk taking and diversification when I measure risk taking using the Distress indicator or 'CAMEL' ratings. ${ }^{17}$ Compared to the OLS results (Table 2), the estimated coefficients from the 2SLS analysis are larger in magnitude. This suggests an attenuation bias due to reverse causality which results in smaller OLS estimates. The instrumental variables, however, allow me to identify a causal impact of changes in competitors' diversification on banks' risk taking.

Using the estimated coefficient reported in column 4 of Panel A of Table 4, I compute that if competitors increase their dispersion across markets by one standard deviation, a bank's probability of failure decreases by about 6 basis points. Since the average annual failure rate of banks is 30 basis points, this implies that a bank's annual risk of bankruptcy decreases by $20 \%$ when competitors increase their diversity by one standard deviation.

\footnotetext{
${ }^{17}$ These results are unreported and are available upon request.
} 


\subsection{Gravity-Deregulation Model}

Instrumental variables at the state-level are not able to capture a bank's decision to expand into other markets, and hence only provide an instrument for the average expansion of banks within a state. Moreover, unobservable state specific time varying effects, such as a state's overall level of bankruptcy risk, might influence my findings.

Therefore, I design a strategy to differentiate the effect of a removal of branching restrictions on banks' expansion, which allows me to (1) account for the endogenous choice of banks to expand within a state, and (2) include state specific time fixed effects to capture unobservable changes within a state. This approach incorporates (a) the timing of intrastate branching deregulation at states, (b) the distance of counties within a state, and (c) differences between banks in regards to their regulatory charter and/or membership to the Federal Reserve System.

\subsubsection{Gravity-Deregulation Model: Strategy}

Frankel and Romer (1999) devise an identification strategy using a gravity model to analyze whether international trade causes economic growth. They determine the effect of several country specific variables on trade flows between countries and construct projected aggregate trade volumes at the country level. In a second step, they use these constructed trade volumes as instruments for actual trade to identify the causal impact of trade on economic growth. Goetz et al. (2011) modify this approach to pin down the causal relationship between a bank holding company's geographic diversification across states in the United States and its market valuation. To do so, they incorporate the state specific process of a removal of (bilateral) interstate banking restrictions in a gravity model to create an instrument that captures a bank holding company's level of geographic diversification.

Building upon their approach, I construct a bank-specific instrumental variable, 
based on the timing of intrastate branching deregulation, the distance of counties in a state, and bank specific characteristics. Specifically, I estimate the effect of distance of a bank's home county and another county on the degree of a bank's expansion into that county. Furthermore, I estimate how that effect changes once states remove their intrastate branching restrictions. In particular, I hypothesize that a bank's share of deposits is larger in counties that are closer to the bank's home county. Moreover, I expect that the effect of distance on a bank's expansion into another county decreased once states removed intrastate branching restrictions.

Additionally, I examine how the relationship between expansion and distance is different across bank types. In particular, I hypothesize that the link between expansion and distance differs by (1) a bank's charter authority (state or national charter) and (2) a bank's membership to the Federal Reserve System. Because of the McFadden Act of 1927 and the Banking Act of 1933, banks in the U.S. are subject to state specific banking laws irrespective of their charter type. Aside from smaller differences, a bank's charter choice determines its primary regulatory agency, which can be associated with additional costs: state chartered banks are supervised by state banking regulators and do not need to bear any costs due to supervision. National chartered banks, on the other hand, are supervised by the Office of the Comptroller of the Currency (OCC), which charges supervisory fees (Blair and Kushmeider (2006)). Anecdotal evidence also suggests, that banks choose state charters because state regulators, in contrast to national regulators, have a better understanding of a bank's business model in light of the local economy. ${ }^{18}$ Hence, a bank's charter choice is supposed to reflect its desire to expand within state borders once states liberalize intrastate branching restrictions.

Aside from this, banks can also decide whether they want to become members of the Federal Reserve System. While national chartered banks are members of

\footnotetext{
${ }^{18}$ See for instance $h t t p: / / w w w . a r k a n s a s . g o v / b a n k / b e n e f i t s \_w h y . h t m l$
} 
the Federal Reserve System by default, state chartered banks can apply for membership. The Federal Reserve bank of the bank's district decides whether to grant membership, and evaluates the bank's application based on factors such as, financial condition or general character of management. Membership to the Federal Reserve System provides banks with additional benefits, such as, for instance, the privilege of voting for directors of the Federal Reserve bank. However, membership to the Federal Reserve System is also costly, as it requires banks to subscribe to the capital stock in the Federal Reserve bank of its district. Moreover, once state chartered banks are members of the Federal Reserve System, they are jointly supervised by the Federal Reserve and state banking regulators - although at no additional costs due to supervision.

Given these differences across bank types, I hypothesize that a removal of branching restrictions has different effects on banks' branching decisions. Compared to state chartered banks, I hypothesize that the effect of distance on expansion changes more for national chartered banks once states remove their branching restrictions. Similarly, I hypothesize that - compared to non-member banks - member banks of

the Federal Reserve System have a greater incentive to expand once states liberalize their branching restrictions, implying that distance becomes less important once branching restrictions are removed.

\subsubsection{Zero-Stage: Distance and Intrastate Branching Deregulation}

The following gravity-deregulation model estimates the effect of distance and size on the expansion of banks within state borders:

$$
\begin{aligned}
\text { Share }_{i, h, c, t} & =\alpha_{1} \ln \left(\text { dist }_{h, c}\right)+\alpha_{2} \ln \left(\text { dist }_{h, c}\right) \times B_{i, t}+ \\
& +\alpha_{3} \ln \left(\text { dist }_{h, c}\right) \times B_{i, t} \times I_{i}+\alpha_{4} \ln \left(\text { dist }_{h, c}\right) \times I_{i}+\Delta_{i, h, c, t}+\varepsilon_{i, h, c, t}
\end{aligned}
$$


where Share $_{i, h, c, t}$ is the share of deposits bank $i$, headquartered in county $h$, holds in branches in county $c$ in year $t$; dist $t_{h, c}$ is the distance (in miles) between county $h$ and county $c ; B_{i, t}$ is a dummy variable taking on the value of one whether bank $i$ 's state removed its intrastate branching restrictions, or zero otherwise; $I_{i}$ is an indicator variable taking on the value of one, (1) whether bank $i$ had a national charter prior to intrastate branching deregulation, (2) and/or was a member of the Federal Reserve System prior to intrastate branching deregulation, or zero otherwise; $\Delta_{i, h, c, t}$ is a set of dummy variables accounting for fixed effects at the bank, county and year level.

The baseline effect of distance on banks' expansion is captured by the coefficient $\alpha_{1}$. Changes of this relationship due to a removal of intrastate branching restrictions are reflected in $\alpha_{2}$. Differential effects because of banks' charter type or their membership to the Federal Reserve System are captured by $\alpha_{3}$. As mentioned above, I hypothesize that banks have less deposits in branches that are further away, i.e. $\alpha_{1}<0$, but I expect this effect to be mitigated once states liberalize branching restrictions, i.e. $\alpha_{2}>0$. Furthermore, I expect that the effect of distance on expansion decreases more for national banks or Federal Reserve member banks once states remove intrastate branching prohibitions.

Table 5 presents results from an OLS estimation of the gravity-deregulation model where I use the share of deposits in $\%$ points as the dependent variable. ${ }^{19}$ The results show that banks have a smaller share of deposits in counties that are further away from the county where they are headquartered in. As hypothesized, the effect of distance on the share of deposits becomes smaller once states remove their branching restrictions. This also holds when I include bank fixed effects (column 2). In columns (3) to (5), I include the aforementioned bank specific variables. Results in Table 5 suggest that distance is less important for a bank's expansion if the bank

\footnotetext{
${ }^{19}$ Due to the size of the data set, I demeaned the dependent and independent variables by hand to capture the reported fixed effects. Standard errors are robust and clustered at the bank level.
} 
is a member of the Federal Reserve System and/or has a national charter.

The bank specific heterogeneity in the effect of distance on banks' expansion within states allows me to construct a projected expansion for each bank and year. To be consistent with my earlier analysis, I estimate the gravity-deregulation model where I use as dependent variable (1) an indicator taking on the value of one whether bank $i$ has a branch in county $c$ in year $t$, and (2) the squared share of deposits bank $i$ holds in county $c$ in year $t$. The projected variables are then aggregated at the bank-year level to construct instrumental variables for (1) a bank's number of active banking markets, and (2) a bank's deposit dispersion across markets. Similar to before, I construct instruments for competitors' expansion by taking the average of each variable in a county without including bank $i$ and assigning it to bank $i$. Similar to the variable construction earlier, the projected relative difference in the degree of geographic diversity is given by the difference between these two values.

\subsubsection{Diversification and Risk Taking: Second-stage}

Table 6 presents second stage regression results using instrumental variables based on the gravity-deregulation model. In particular, I use the gravity models of column 4 in Table 5 to construct instruments for a bank's level of geographic diversity and the diversity of its competitors. Because the gravity-deregulation model allows me to account for a bank's own diversification activity, I include all bank-year observations in my analysis.

Consistent with earlier findings, results in Table 6 indicate that banks' risk taking decreases when the relative difference in diversification between banks and their competitors increases. This is not sensitive to the definition of diversification as I find a statistically significant effect between diversification and risk taking when I use the difference between a bank's dispersion of deposits across counties and the deposit dispersion of a bank's competitors' (column 1) or the difference in their 
number of markets (column 2). Because the gravity-deregulation model provides an instrumental variable at the bank level, I can separately identify (a) the impact of a bank's own level of diversification on its risk taking behavior and (b) the impact of a bank's competitors' changes in diversification on risk taking. The findings in Table 6 suggest that risk taking significantly increases when a bank diversifies its activity across markets, consistent with earlier work by Demsetz and Strahan (1997). However, when competitors increase their level of diversification across counties, a bank's risk taking significantly decreases. This pattern is consistent with the theoretical model since the model shows that the effect of a bank's diversification on its own exposure to risk of failure is different than the effect of competing banks' risk. Moreover, this finding is not sensitive to the definition of diversification as it also holds when I use the number of markets, a bank is active in to capture its degree of diversification. Furthermore, I also include state-year fixed effects in Table 6. These fixed effects capture unobservable, time-varying changes at the state level and hence account for other confounding effects at the state level, such as changes in overall bankruptcy risk at the state.

\section{Conclusion}

I present a theoretical model building on earlier work from Stein (2002) and Acharya et al. (2011), to show how a bank's diversification not only affects its own risk taking behavior, but also the risk taking behavior of competing banks. In particular, the model argues that a greater degree of geographic diversification has not only an effect on a bank's exposure to risk of failure, but also - due to competition for borrowers in the market - an effect on competing bank's risk taking.

To examine this pattern empirically, I analyze the relationship between diversification and risk taking empirically using data from U.S. commercial banks and 
find evidence consistent with this model. OLS regression results indicate that the level of competitors' degree of diversification is significantly correlated with bank's risk taking behavior. Moreover, I use the staggered timing of intrastate branching deregulation, and a gravity-deregulation model to pin down the causal relationship of banks' diversification on risk taking of competing banks. Regression results indicate that banks decrease risk taking when competitors increase their branch network across counties or when their dispersion of deposits across markets changes. My results also indicate that a bank's own risk taking increases when it diversifies across markets. Hence, these findings suggest that there are indirect effects of diversification, as a bank's risk taking is also affected as competitors change their diversification. 


\section{References}

Acharya, V. V., S. C. Myers, and R. G. Rajan (2011): "The Internal Governance of Firms," Journal of Finance, 66, 689-720.

Amel, D. And N. Liang (1992): "The Relationship between Entry into Banking Markets and Changes in Legal Restrictions on Entry," Antitrust Bulletin, 631 649.

Beck, T., R. Levine, And A. Levkov (2010): "Big Bad Banks: The Winners and Losers from Bank Deregulation in the United States," Journal of Finance, $65,1637-1667$.

Berger, A. N. And T. H. Hannan (1989): "The Price-Concentration Relationship in Banking," The Review of Economics and Statistics, 291 - 299.

Berger, A. N., N. H. Miller, M. A. Petersen, R. G. Rajan, and J. C. STEIN (2005): "Does function follow organizational form? Evidence from the lending practices of large and small banks," Journal of Financial Economics, 76, $237-269$.

Blair, C. E. And R. M. Kushmeider (2006): "Challenges to the Dual Banking System: The Funding of Bank Supervision," FDIC Banking Review, 18, 1 - 22.

Boot, A. W. A. And A. Schmeits (2000): "Market Discipline and Incentive Problems in Conglomerate Firms with Applications to Banking," Journal of Financial Intermediation, 9, $240-273$.

Boyd, J. H. And G. De Nicolo (2005): "The Theory of Bank Risk Taking and Competition Revisited," Journal of Finance, 60, 1329-1343.

Boyd, J. H., G. De Nicolo, And A. M. Jalal (2007): "Bank Risk-Taking and 
Competition Revisited: New Theory and New Evidence," IMF working paper $\mathrm{WP} / 06 / 297$.

Boyd, J. H., G. De Nicolo, And E. Loukoianova (2009): "Banking Crises and Crisis Dating: Theory and Evidence," IMF working paper WP/09/141.

Calomiris, C. W. And J. R. Mason (2000): "Causes of U.S. Bank Distress during the depression," NBER working paper 7919.

Carlson, M. And K. J. Mitchener (2009): "Branch Banking as a Device for Discipline: Competition and Bank Survivorship during the Great Depression," Journal of Political Economy, 117, 165-210.

DE Nicolo, G. (2000): "Size, charter value and risk in banking: an international perspective," Board of Governors of the Federal Reserve System, International Finance Discussion Paper No.689.

Dell'Ariccia, G. And R. MARquez (2004): "Information and bank credit allocation," Journal of Financial Economics, 72, 185-214.

- (2010): "Risk and the Corporate Structure of Banks," Journal of Finance, 65, 1075-1096.

Demsetz, R. S. And P. E. Strahan (1997): "Diversification, Size, and Risk at Bank Holding Companies," Journal of Money, Credit, and Banking, 29, 300-313.

Diamond, D. (1984): "Financial intermediation and delegated monitoring," Review of Economic Studies, 51, 393-414.

Frankel, J. A. And D. Romer (1999): "Does Trade Cause Growth?" American Economic Review, 89, 379-399.

Goetz, M., L. Laeven, And R. Levine (2011): "The Valuation Effects of Geographically Diversified Bank Holding Companies," Mimeo. 
Hertzberg, A., J. M. Liberti, And D. Paravisini (2010): "Information and Incentives Inside the Firm: Evidence from Loan Officer Rotation," Journal of Finance, 65, 795-828.

Jayaratne, J. And P. E. Strahan (1996): "The Finance-Growth Nexus: Evidence from Bank Branch Deregulation," Quarterly Journal of Economics, 111, $639-670$.

Jimenez, G., J. A. Lopez, And J. SAurina (2010): "How does Competition Impact Bank Risk-Taking?" Mimeo, Banco de Espana.

Keeley, M. C. (1990): "Deposit Insurance, Risk, and Market Power in Banking," American Economic Review, 80, 1183-1199.

Kroszner, R. S. And P. E. Strahan (1999): "What Drives Deregulation? Economics and Politics of the Relaxation of Bank Branching Restrictions," Quarterly Journal of Economics, 114, 1437-1467.

Laeven, L., P. Bongini, And G. Majnoni (2002): "How Good is the Market at Assessing Bank Fragility? A Horse Race Between Different Indicators," Journal of Banking and Finance, 26, 1011-1028.

LAEven, L. AND R. LEvine (2009): "Bank governance, regulation and risk taking," Journal of Financial Economics, 93, 259-275.

Liberti, J. M. And A. R. Mian (2009): "Estimating the Effect of Hierarchies on Information Use," The Review of Financial Studies, 22, 4057-4090.

Martinez-Miera, D. And R. Repullo (2010): "Does Competition Reduce the Risk of Bank Failure?" Review of Financial Studies, 23, 3638-3664.

Mitchener, K. J. (2005): "Bank Supervision, Regulation, and Instability During the Great Depression," The Journal of Economic History, 65, 152-185. 
Morgan, D. P. (2002): "Rating Banks: Risk and Uncertainty in an Opaque Industry," American Economic Review, 92, 874-888.

Morgan, D. P., B. Rime, And P. E. Strahan (2004): "Bank Integration and State Business Cycles," Quarterly Journal of Economics, 1555-1584.

Petersen, M. A. And R. G. Rajan (1995): "The Effect of Credit Market Competition on Lending Relationships," Quarterly Journal of Economics, 110, 407-443.

Roy, A. (1952): "Safety First and the Holding of Assets," Econometrica, 431-449.

Stein, J. C. (2002): "Information Production and Capital Allocation: Decentralized versus Hierarchical Firms," Journal of Finance, 57, 1891-1921. 


\section{Figures}

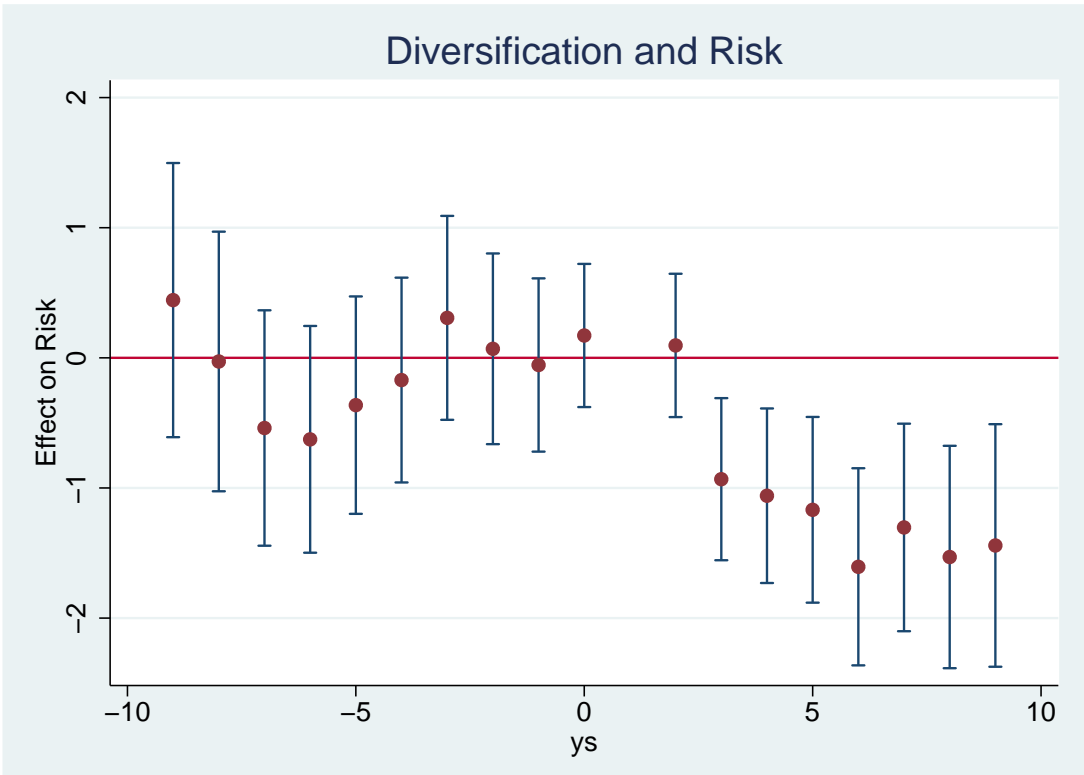

Figure 1: Effects of Competitor's Expansion on Risk Taking

Note: This figure illustrates the dynamic effects of a competitor's expansion on a bank's risk taking. The regression model is given as $\left.R_{i, t}\right)=\sum_{p=-10}^{10} \alpha_{p} Y_{p, i, t}+\tilde{\delta_{i}}+\tilde{\delta_{t}}+\tau_{i, s, t}$ where $R_{i, t}$ ) is the Inverse Z-Score of bank $i$ in year $t, Y_{p, i, t}$ is a dummy variable that takes on the value of one if in year $t$ the competitor of bank $i$ expands its branch network in $p$ years. The figure plots the estimates on the dummy variables $\left(\alpha_{p}\right)$ as well as the 95 percent confidence interval for these estimates. The regression adjusts for bank-level clustering and centers around the year of expansion. Coefficients at the end points $(\alpha-10, \alpha+10)$ are omitted.

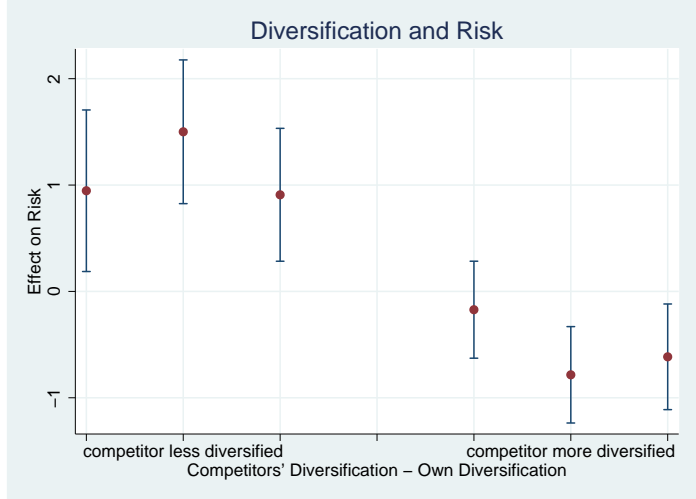

(a) Measure: Deposit Concentration)

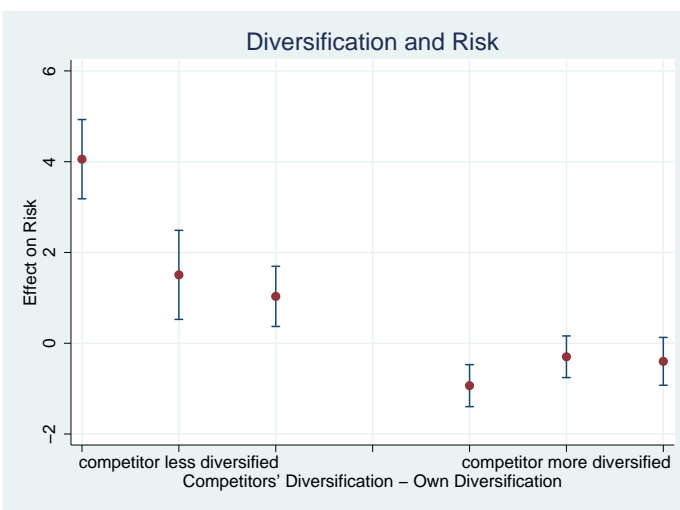

(b) Measure: $\ln ($ number of markets)

Figure 2: Difference in Organizational Scope and Risk

Note: This figure plots the year of intrastate deregulation against the level/change of bank risk. Bank risk at the state level is measured by the median Inverse Z-score in that state. 


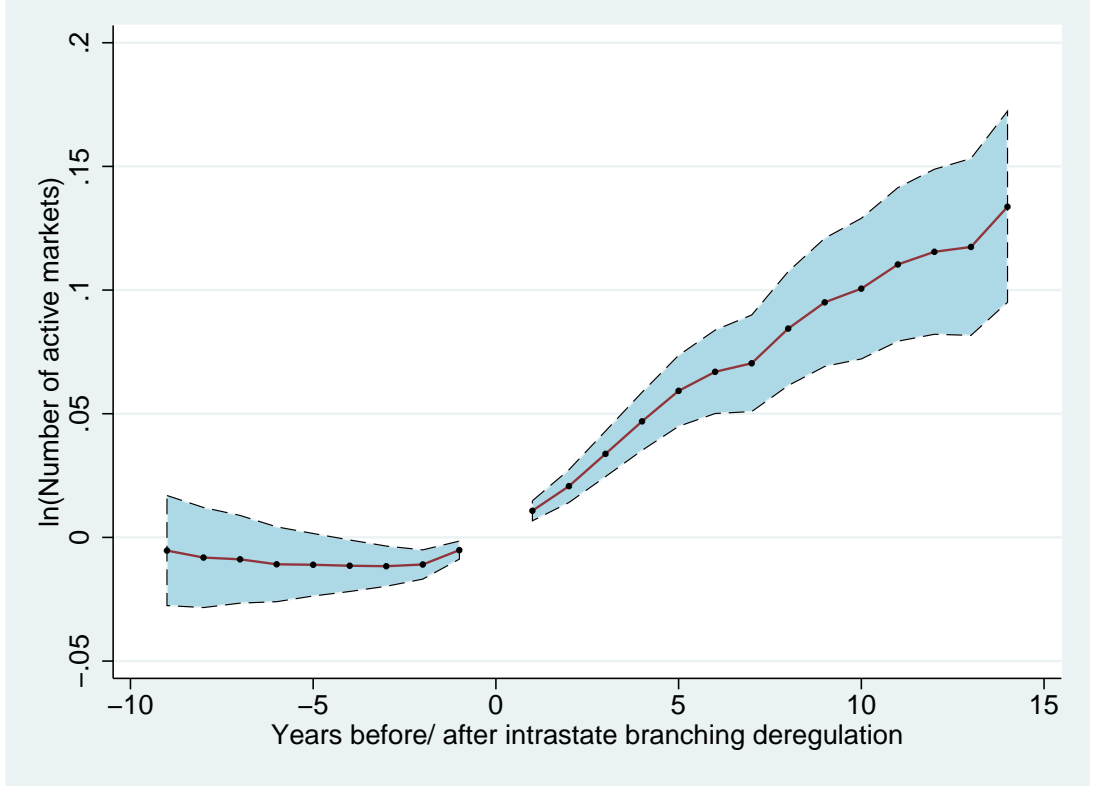

Figure 3: Effects of intrastate branching deregulation on organizational structure Note: This figure illustrates the dynamic effects of intrastate branching deregulation on the natural log of banking markets. The regression model is given as $\ln \left(M_{i, s, t}\right)=\sum_{p=-10}^{15} \alpha_{p} Y_{p, s, t}+\tilde{\delta}_{i}+\tilde{\delta}_{t}+\tau_{i, s, t}$ where $\ln \left(M_{i, s, t}\right)$ is the $\log$ number of banking markets bank $i$, located in state $s$, is active in during year $t, Y_{p, s, t}$ is a dummy variable that takes on the value of one if in year $t$ deregulation in a state $s$ is in $p$ years. The figure plots the estimates on the dummy variables $\left(\alpha_{p}\right)$ as well as the 95 percent confidence interval for these estimates. The regression adjusts for bank-level clustering and centers around the year of deregulation. 


\section{Tables}

Table 1: Summary Statistics

Inverse Z-Score

Distress Indicator

CAMEL-Indicator

Return on Assets (in \%)

$=1$ if bank part of Bank Holding Company Capital-Asset-Ratio (in \%)

Total Assets (in 1,000,000 \$)

Total Assets (in 1,000,000 \$)

Herfindahl Index of deposits across coun-

ties

$\ln$ (Number of competitor's banking mar-

kets)

1 - Competitor's Herfindahl Index of deposits across counties

Growth of county personal income

Growth of county personal income (lag)

$\ln$ (Number of Branches in County)

$\ln$ (Number of Banks in County)

Population per branch in county (in

$1,000 \mathrm{~s})$

Herfindahl Index of deposits in county

\begin{tabular}{llllll}
\hline \multicolumn{5}{c}{ Nondiversified BANKS } \\
\multicolumn{7}{c}{ Std.Dev. Min } & Max & Median \\
$\mathbf{N}$ & \multirow{5}{c}{ Mean } & Std & & \\
\hline & & & & \\
211,278 & 24.415 & 20.385 & 3.309 & 126.551 & 17.827 \\
209,951 & 0.022 & 0.147 & 0 & 1 & 0 \\
134,351 & 0.868 & 0.913 & 0 & 4 & 1 \\
211,278 & 0.579 & 0.334 & -2.294 & 1.707 & 0.576 \\
211,278 & 0.567 & 0.496 & 0 & 1 & 1 \\
211,278 & 9.345 & 2.883 & 4.007 & 32.295 & 8.688 \\
211,278 & 0.547 & 0.14 & 0 & 1.323 & 0.56 \\
211,278 & 70.874 & 331.289 & 0.633 & 37700 & 34.503 \\
211,278 & 0 & 0 & 0 & 0 & 0 \\
211,278 & 0 & 0 & 0 & 0 & 0 \\
& & & & & \\
202,437 & 0.172 & 0.336 & 0 & 3.912 & 0 \\
& & & & & \\
202,437 & 0.078 & 0.155 & 0 & 1 & 0 \\
& & & & & \\
210,367 & 0.075 & 0.067 & -0.682 & 2.641 & 0.069 \\
210,364 & 0.077 & 0.069 & -0.682 & 2.641 & 0.072 \\
211,278 & 2.778 & 1.249 & 0 & 7.054 & 2.565 \\
211,278 & 1.887 & 1.024 & 0 & 5.598 & 1.792 \\
210,370 & 3.973 & 2.778 & 0.329 & 162.674 & 3.304 \\
& & & & & \\
211,278 & 0.109 & 0.129 & 0 & 1 & 0.082 \\
\hline
\end{tabular}

\begin{tabular}{|c|c|c|c|c|c|}
\hline \multirow[b]{2}{*}{$\mathbf{N}$} & \multicolumn{3}{|c|}{ Diversified BANKS } & \multirow[b]{2}{*}{$\operatorname{Max}$} & \multirow[b]{2}{*}{ Median } \\
\hline & Mean & Std.Dev. & Min & & \\
\hline 43077 & 18.687 & 16.539 & 3.312 & 126.268 & 13.608 \\
\hline 42934 & 0.01 & 0.099 & 0 & 1 & 0 \\
\hline 36871 & 1.053 & 0.939 & 0 & 4 & 1 \\
\hline 43077 & 0.544 & 0.273 & -1.944 & 1.704 & 0.541 \\
\hline 43077 & 0.78 & 0.414 & 0 & 1 & 1 \\
\hline 43077 & 8.663 & 2.33 & 4.009 & 30.975 & 8.25 \\
\hline 43077 & 0.61 & 0.129 & 0.077 & 1.054 & 0.623 \\
\hline 43077 & 444.596 & 1579.91 & 3.494 & 52600 & 118.873 \\
\hline 43077 & 1.005 & 0.54 & 0.693 & 4.357 & 0.693 \\
\hline 43077 & 0.587 & 0.278 & 0 & 1 & 0.619 \\
\hline 38745 & 0.513 & 0.573 & 0 & 4.718 & 0.405 \\
\hline 38745 & 0.218 & 0.237 & 0 & 1 & 0.156 \\
\hline 42297 & 0.061 & 0.05 & -0.456 & 2.132 & 0.059 \\
\hline 42295 & 0.063 & 0.05 & -0.664 & 1.167 & 0.06 \\
\hline 43077 & 3.119 & 1.263 & 0 & 7.054 & 2.89 \\
\hline 43077 & 1.475 & 0.901 & 0 & 5.509 & 1.386 \\
\hline 42299 & 3.516 & 3.276 & 0.046 & 160.136 & 3.129 \\
\hline 43077 & 0.124 & 0.12 & 0 & 1 & 0.097 \\
\hline
\end{tabular}

This table reports descriptive statistics. Nondiversified banks are banks with branches in only one county. Diversified banks are banks with branches in at least two counties. 
Table 2: Geographic Diversification and Bank Risk

\begin{tabular}{|c|c|c|c|c|c|c|}
\hline & $(1)$ & $(2)$ & $(3)$ & $(4)$ & $(5)$ & $(6)$ \\
\hline Diversification Difference (HHI of deposits) & $\begin{array}{l}-1.591^{* * *} \\
(0.332)\end{array}$ & $\begin{array}{l}-1.510^{* * *} \\
(0.336)\end{array}$ & $\begin{array}{l}-1.614^{* * *} \\
(0.337)\end{array}$ & $\begin{array}{l}-1.641^{* * *} \\
(0.336)\end{array}$ & $\begin{array}{l}-1.839^{* * *} \\
(0.333)\end{array}$ & \\
\hline Diversification Difference (Number of markets) & & & & & & $\begin{array}{l}-1.643^{* * *} \\
(0.196)\end{array}$ \\
\hline Capital-Asset-Ratio & & $\begin{array}{l}-1.953^{* * *} \\
(0.035)\end{array}$ & $\begin{array}{l}-1.967^{* * *} \\
(0.035)\end{array}$ & $\begin{array}{l}-1.966^{* * *} \\
(0.035)\end{array}$ & $\begin{array}{l}-1.965^{* * *} \\
(0.035)\end{array}$ & $\begin{array}{l}-1.974^{* * *} \\
(0.035)\end{array}$ \\
\hline Total Loans / Total Assets & & $\begin{array}{l}5.254 * * * \\
(0.660)\end{array}$ & $\begin{array}{l}5.011 * * * \\
(0.661)\end{array}$ & $\begin{array}{l}5.093 * * * \\
(0.668)\end{array}$ & $\begin{array}{l}5.115^{* * * *} \\
(0.690)\end{array}$ & $\begin{array}{l}5.107^{* * *} \\
(0.690)\end{array}$ \\
\hline$=1$ if bank part of Bank Holding Company & & $\begin{array}{l}-2.192^{* * *} \\
(0.206)\end{array}$ & $\begin{array}{l}-2.213^{* * *} \\
(0.206)\end{array}$ & $\begin{array}{l}-2.273^{* * *} \\
(0.207)\end{array}$ & $\begin{array}{l}-2.305^{* * *} \\
(0.208)\end{array}$ & $\begin{array}{l}-2.299^{* * *} \\
(0.208)\end{array}$ \\
\hline $\ln$ (Total Assets) & & $\begin{array}{l}-3.876^{* * *} \\
(0.240)\end{array}$ & $\begin{array}{l}-4.123^{* * *} \\
(0.247)\end{array}$ & $\begin{array}{l}-4.459^{* * *} \\
(0.247)\end{array}$ & $\begin{array}{l}-5.183^{* * *} \\
(0.255)\end{array}$ & $\begin{array}{l}-5.342^{* * *} \\
(0.254)\end{array}$ \\
\hline Growth of county personal income & & & $\begin{array}{l}-9.916^{* * *} \\
(0.794)\end{array}$ & $\begin{array}{l}-8.959^{* * *} \\
(0.791)\end{array}$ & $\begin{array}{l}-3.493^{* * *} \\
(0.830)\end{array}$ & $\begin{array}{l}-3.501^{* * *} \\
(0.830)\end{array}$ \\
\hline Growth of county personal income (lag) & & & $\begin{array}{l}-9.071^{* * *} \\
(0.753)\end{array}$ & $\begin{array}{l}-8.412^{* * *} \\
(0.750)\end{array}$ & $\begin{array}{l}-3.233^{* * *} \\
(0.805)\end{array}$ & $\begin{array}{l}-3.237^{* * *} \\
(0.805)\end{array}$ \\
\hline $\ln$ (Number of Branches in County) & & & $\begin{array}{l}3.375^{* * * *} \\
(0.560)\end{array}$ & $\begin{array}{l}2.802^{* * *} \\
(0.572)\end{array}$ & $\begin{array}{l}2.098^{* * *} \\
(0.623)\end{array}$ & $\begin{array}{l}2.176^{* * *} \\
(0.623)\end{array}$ \\
\hline $\ln$ (Number of Banks in County) & & & $\begin{array}{l}1.648^{* * * *} \\
(0.321)\end{array}$ & $\begin{array}{l}1.432 * * * \\
(0.322)\end{array}$ & $\begin{array}{l}0.154 \\
(0.352)\end{array}$ & $\begin{array}{l}0.088 \\
(0.352)\end{array}$ \\
\hline Population per branch in county & & & $\begin{array}{l}0.020 \\
(0.112)\end{array}$ & $\begin{array}{l}-0.112 \\
(0.115)\end{array}$ & $\begin{array}{l}-0.259^{* *} \\
(0.128)\end{array}$ & $\begin{array}{l}-0.272^{* *} \\
(0.128)\end{array}$ \\
\hline Herfindahl Index of deposits in county & & & $\begin{array}{l}6.928^{* * *} \\
(1.476)\end{array}$ & $\begin{array}{l}7.159^{* * *} \\
(1.479)\end{array}$ & $\begin{array}{l}7.426^{* * *} \\
(1.479)\end{array}$ & $\begin{array}{l}7.541^{* * *} \\
(1.480)\end{array}$ \\
\hline Bank fixed effects & $\checkmark$ & $\checkmark$ & $\checkmark$ & $\checkmark$ & $\checkmark$ & $\checkmark$ \\
\hline Year fixed Effects & $\checkmark$ & $\checkmark$ & $\checkmark$ & & & \\
\hline Region-Year fixed effects & & & & $\checkmark$ & & \\
\hline State-Year fixed effects & & & & & $\checkmark$ & $\checkmark$ \\
\hline Observations & 241,182 & 241,182 & 239,825 & 239,825 & 239,825 & 239,825 \\
\hline Number of Banks & 16,845 & 16,845 & 16,662 & 16,662 & 16,662 & 16,662 \\
\hline
\end{tabular}


Table 3: Geographic Diversification and Bank Risk - Robustness

\begin{tabular}{|c|c|c|c|c|c|c|}
\hline & $(1)$ & $(2)$ & $(3)$ & $(4)$ & $(5)$ & $(6)$ \\
\hline & \multicolumn{2}{|c|}{ Alternative Risk Measures: } & & \multicolumn{2}{|c|}{ Subsamples - Exclude ... } & \multirow[b]{2}{*}{$\begin{array}{l}\text {...every third } \\
\text { year }\end{array}$} \\
\hline & $\begin{array}{l}\text { Distress } \\
\text { Indicator }\end{array}$ & $\begin{array}{l}\text { 'CAMEL' } \\
\text { Ratings }\end{array}$ & $\begin{array}{l}\text {...exiting } \\
\text { banks }\end{array}$ & $\begin{array}{l}\ldots+/-1 \text { year } \\
\text { around } \\
\text { acquisition }\end{array}$ & $\begin{array}{l}\ldots \text { once a } \\
\text { bank } \\
\text { acquires } \\
\text { another bank }\end{array}$ & \\
\hline Diversification Difference (HHI of deposits) & $\begin{array}{l}-0.024^{* * *} \\
(0.002)\end{array}$ & $\begin{array}{l}-0.244^{* * *} \\
(0.016)\end{array}$ & $\begin{array}{l}-1.037^{* *} \\
(0.440)\end{array}$ & $\begin{array}{l}-0.944^{* *} \\
(0.433)\end{array}$ & $\begin{array}{l}-0.824^{*} \\
(0.421)\end{array}$ & $\begin{array}{l}-1.563^{* * *} \\
(0.476)\end{array}$ \\
\hline Capital-Asset-Ratio & $\begin{array}{l}0.013^{* * *} \\
(0.000)\end{array}$ & $\begin{array}{l}-0.030^{* * *} \\
(0.001)\end{array}$ & $\begin{array}{l}-1.674^{* * *} \\
(0.047)\end{array}$ & $\begin{array}{l}-2.004^{* * *} \\
(0.040)\end{array}$ & $\begin{array}{l}-2.230^{* * *} \\
(0.045)\end{array}$ & $\begin{array}{l}-2.211^{* * *} \\
(0.052)\end{array}$ \\
\hline Total Loans / Total Assets & $\begin{array}{l}0.040^{* * *} \\
(0.005)\end{array}$ & $\begin{array}{l}0.898^{* * *} \\
(0.033)\end{array}$ & $\begin{array}{l}7.178^{* * *} \\
(0.955)\end{array}$ & $\begin{array}{l}5.287^{* * *} \\
(0.775)\end{array}$ & $\begin{array}{l}5.547^{* * *} \\
(0.786)\end{array}$ & $\begin{array}{l}5.618^{* * *} \\
(0.964)\end{array}$ \\
\hline$=1$ if bank part of Bank Holding Company & $\begin{array}{l}0.002^{*} \\
(0.001)\end{array}$ & $\begin{array}{l}-0.020^{*} \\
(0.011)\end{array}$ & $\begin{array}{l}-1.725^{* * *} \\
(0.296)\end{array}$ & $\begin{array}{l}-1.899^{* * *} \\
(0.232)\end{array}$ & $\begin{array}{l}-1.933^{* * *} \\
(0.225)\end{array}$ & $\begin{array}{l}-2.358^{* * *} \\
(0.271)\end{array}$ \\
\hline $\ln$ (Total Assets) & $\begin{array}{l}-0.054^{* * *} \\
(0.002)\end{array}$ & $\begin{array}{l}-0.191^{* * *} \\
(0.013)\end{array}$ & $\begin{array}{l}-4.888^{* * *} \\
(0.344)\end{array}$ & $\begin{array}{l}-6.566^{* * *} \\
(0.308)\end{array}$ & $\begin{array}{l}-4.797^{* * *} \\
(0.313)\end{array}$ & $\begin{array}{l}-4.074^{* * *} \\
(0.345)\end{array}$ \\
\hline Growth of county personal income & $\begin{array}{l}0.014^{* *} \\
(0.006)\end{array}$ & $\begin{array}{l}-0.071 \\
(0.051)\end{array}$ & $\begin{array}{l}-2.026^{*} \\
(1.073)\end{array}$ & $\begin{array}{l}-3.953^{* * *} \\
(0.925)\end{array}$ & $\begin{array}{l}-3.151^{* * * *} \\
(0.921)\end{array}$ & $\begin{array}{c}-3.463^{*} \\
(1.945)\end{array}$ \\
\hline Growth of county personal income (lag) & $\begin{array}{l}0.008 \\
(0.005)\end{array}$ & $\begin{array}{l}-0.216^{* * *} \\
(0.051)\end{array}$ & $\begin{array}{l}-2.366^{* *} \\
(1.043)\end{array}$ & $\begin{array}{l}-3.029 * * * \\
(0.893)\end{array}$ & $\begin{array}{l}-2.989^{* * *} \\
(0.874)\end{array}$ & $\begin{array}{l}1.248 \\
(1.620)\end{array}$ \\
\hline $\ln$ (Number of Branches in County) & $\begin{array}{l}0.010^{* *} \\
(0.004)\end{array}$ & $\begin{array}{l}0.150^{* * *} \\
(0.031)\end{array}$ & $\begin{array}{l}2.081^{* *} \\
(0.848)\end{array}$ & $\begin{array}{l}2.306^{* * *} \\
(0.684)\end{array}$ & $\begin{array}{l}2.212^{* * *} \\
(0.694)\end{array}$ & $\begin{array}{l}2.828^{* * *} \\
(0.839)\end{array}$ \\
\hline $\ln$ (Number of Banks in County) & $\begin{array}{l}-0.002 \\
(0.002)\end{array}$ & $\begin{array}{l}0.003 \\
(0.017)\end{array}$ & $\begin{array}{l}-0.670 \\
(0.453)\end{array}$ & $\begin{array}{l}0.059 \\
(0.407)\end{array}$ & $\begin{array}{l}-0.157 \\
(0.403)\end{array}$ & $\begin{array}{l}-0.068 \\
(0.457)\end{array}$ \\
\hline Population per branch in county & $\begin{array}{l}0.001 \\
(0.001)\end{array}$ & $\begin{array}{l}0.014 * * \\
(0.007)\end{array}$ & $\begin{array}{l}-0.076 \\
(0.204)\end{array}$ & $\begin{array}{l}-0.190 \\
(0.140)\end{array}$ & $\begin{array}{l}-0.006 \\
(0.145)\end{array}$ & $\begin{array}{l}-0.118 \\
(0.182)\end{array}$ \\
\hline Herfindahl Index of deposits in county & $\begin{array}{l}0.063^{* * *} \\
(0.011)\end{array}$ & $\begin{array}{l}0.401^{* * *} * \\
(0.068)\end{array}$ & $\begin{array}{l}6.022^{* * *} \\
(1.841)\end{array}$ & $\begin{array}{l}5.618^{* * *} \\
(1.649)\end{array}$ & $\begin{array}{l}6.046^{* * *} \\
(1.633)\end{array}$ & $\begin{array}{l}6.691^{* * *} \\
(2.058)\end{array}$ \\
\hline Bank fixed effects & $\checkmark$ & $\checkmark$ & $\checkmark$ & $\checkmark$ & $\checkmark$ & $\checkmark$ \\
\hline State-Year fixed effects & $\checkmark$ & $\checkmark$ & $\checkmark$ & $\checkmark$ & $\checkmark$ & $\checkmark$ \\
\hline Observations & 252,729 & 182,445 & 115,826 & 194,791 & 191,976 & 72,746 \\
\hline Number of Banks & 16,761 & 15,677 & 5,765 & 14,207 & 15,365 & 15,517 \\
\hline $\begin{array}{l}\text { This table reports regression results from a bank an } \\
\text { ratio of a bank falls by at least } 1 \% \text {-point in two co } \\
\text { Subsamples from models } 3 \text { to } 6 \text { are given in the sec } \\
\text { between the a bank's deposit dispersion across mar } \\
\text { t - personal income in year t-1)/(personal income in } \\
\text { Capital-Asset-Ratio is defined as (Bank Capital)/ } / \\
\text { 'Ln(Number of Banks in County) ' is the natural log } \\
\text { in the banking market, 'Population per branch' is } \\
\text { of deposits across competitors in a banking marke } \\
\text { Significance stars are: }{ }^{*} p<0.10, * * \text { p }<0.05, * * * \text { p }\end{array}$ & $\begin{array}{l}\text { hartered be } \\
\text { of county } \\
\text { stant is no }\end{array}$ & $\begin{array}{l}\text { he banking } m \\
\text { on (in 1000) } \\
\text { ed. Standard }\end{array}$ & $\begin{array}{l}\text { or' is an in } \\
1 \text { to } 5 \text { whe } \\
\text { iversificatic } \\
\text { trowth of } \mathrm{p} \\
\text { tal Loans) } \\
\text { upany' is ec } \\
\text { Number of } \mathrm{I} \\
\text { anches; 'He } \\
\text { robust, clus }\end{array}$ & $\begin{array}{l}\text { variable taking } \\
\text { er values indica } \\
\text { erence (Number } \\
\text { lincome in year } \\
\text { Assets); ln(tota } \\
\text { one if the banl } \\
\text { en in County)' } 1 \text { is } \\
1 \text { Index of depo } \\
\text { at the bank leve }\end{array}$ & $\begin{array}{l}\text { the value of one if } \\
\text { preater risk (Laeve } \\
\text { Markets)' is the re } \\
\text { s given as (persona } \\
\text { ssets) = natural lo } \\
\text { part of a bank h } \\
\text { e natural logarithr } \\
\text { in county' is the I } \\
\text { nd reported in pa }\end{array}$ & $\begin{array}{l}\text { ne capital-asset } \\
\text { et al. }(2002)) \text {. } \\
\text { ative difference } \\
\text { income in year } \\
\text { of total assets; } \\
\text { ding company; } \\
\text { of all branches } \\
\text { erfindahl Index } \\
\text { entheses below. }\end{array}$ \\
\hline
\end{tabular}


Table 4: The impact of Competitor's Diversification on Bank Risk - Instruments based on Intrastate Branching Deregulation

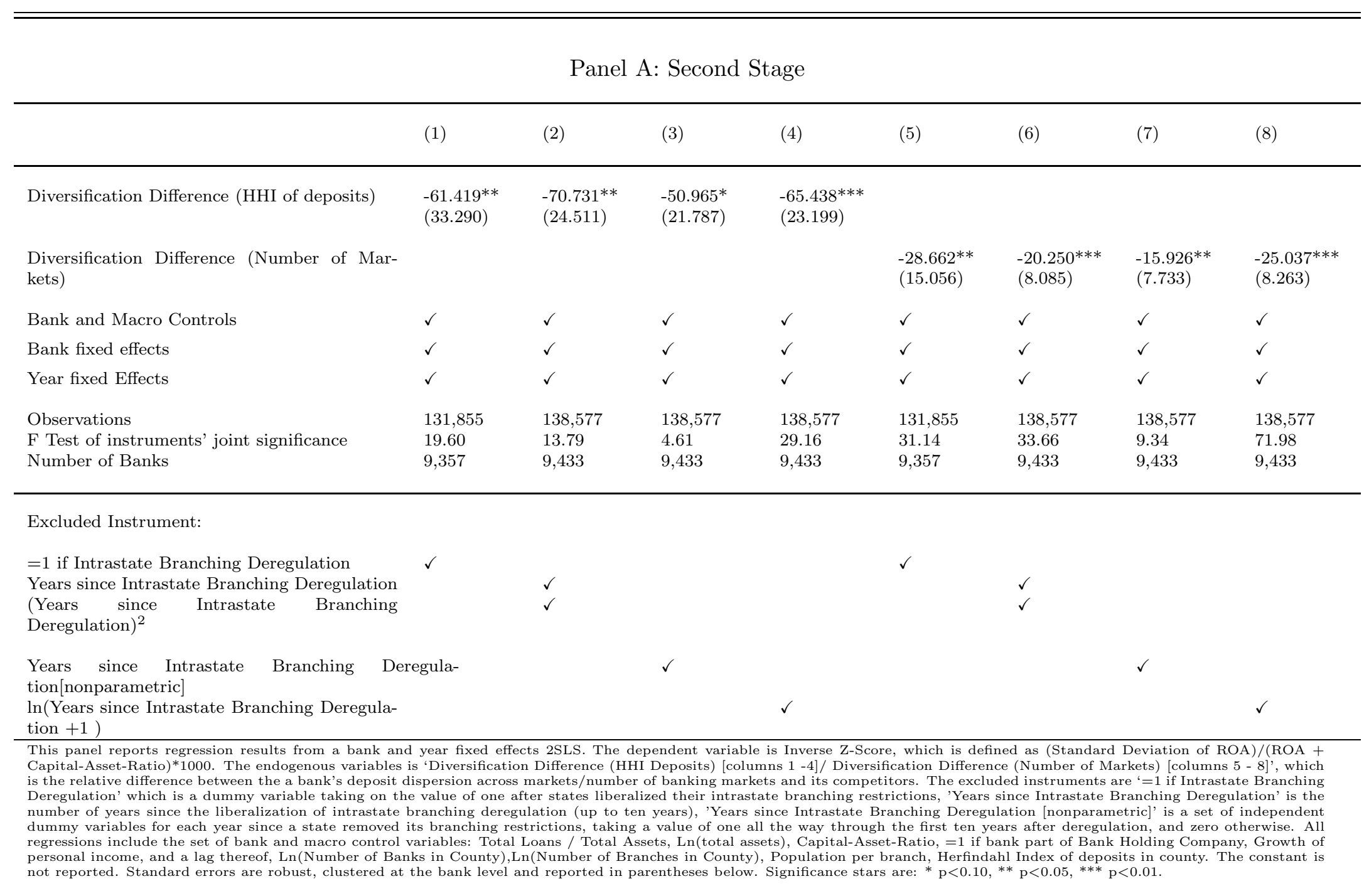


Panel B: First Stage

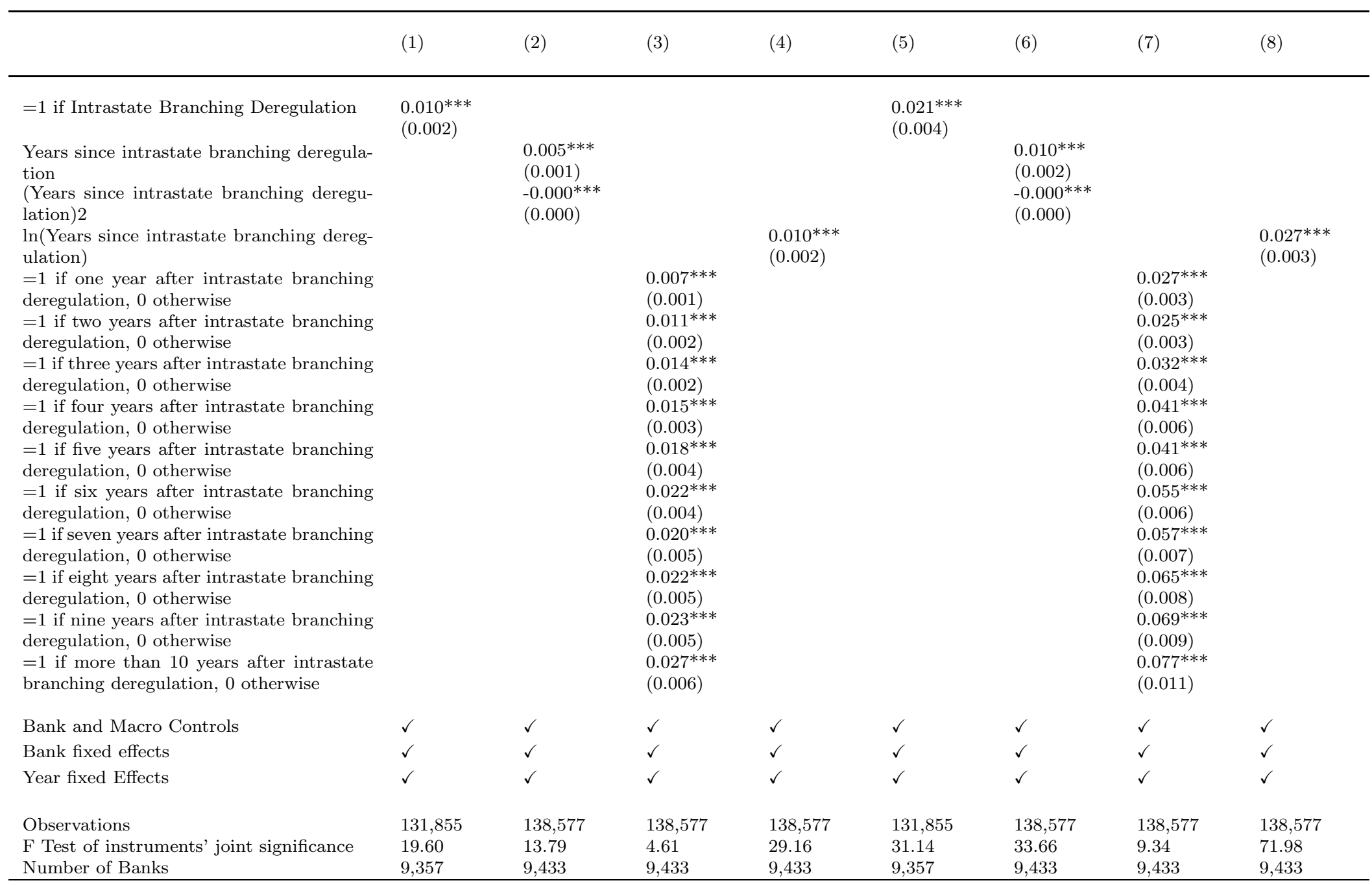


Table 5: The relationship between distance and banks' deposit holdings: Zero-Stage

\begin{tabular}{|c|c|c|c|c|c|c|}
\hline & & $(1)$ & $(2)$ & $(3)$ & $(4)$ & $(5)$ \\
\hline & $\ln$ (Distance in miles) & $\begin{array}{l}-8.144^{* * *} \\
(0.043)\end{array}$ & $\begin{array}{l}-8.144^{* * *} \\
(0.043)\end{array}$ & $\begin{array}{l}-8.264^{* * *} \\
(0.054)\end{array}$ & $\begin{array}{l}-8.348^{* * *} \\
(0.050)\end{array}$ & $\begin{array}{l}-8.264^{* * *} \\
(0.054)\end{array}$ \\
\hline & $\begin{array}{l}(=1 \text { if Intrastate Branching Deregu- } \\
\text { lation }) * \ln (\text { Distance (in miles }))\end{array}$ & $\begin{array}{l}0.014^{* * *} \\
(0.001)\end{array}$ & $\begin{array}{l}0.015^{* * *} \\
(0.001)\end{array}$ & $\begin{array}{l}0.012^{* * *} \\
(0.001)\end{array}$ & $\begin{array}{l}0.013^{* * *} \\
(0.001)\end{array}$ & $\begin{array}{l}0.012^{* * *} \\
(0.001)\end{array}$ \\
\hline $\begin{array}{l}(=1 \text { if bank was member of Federal } \\
\text { Reserve System prior to Branching } \\
\text { Deregulation })\end{array}$ & $\begin{array}{l}*(=1 \text { if Intrastate Branching Dereg- } \\
\text { ulation }) * \ln (\text { Distance (in miles) })\end{array}$ & & & $\begin{array}{l}0.008^{* * *} \\
(0.002)\end{array}$ & & $\begin{array}{l}0.013^{* * *} \\
(0.004)\end{array}$ \\
\hline $\begin{array}{l}(=1 \text { if bank held Federal Banking } \\
\text { Charter prior to Branching Deregula- } \\
\text { tion }) *\end{array}$ & $\begin{array}{l}*(=1 \text { if Intrastate Branching Dereg- } \\
\text { ulation }) * \ln (\text { Distance (in miles }))\end{array}$ & & & & $\begin{array}{l}0.004^{* *} \\
(0.002)\end{array}$ & $\begin{array}{c}-0.007^{*} \\
(0.004)\end{array}$ \\
\hline & County fixed effects & $\checkmark$ & $\checkmark$ & $\checkmark$ & $\checkmark$ & $\checkmark$ \\
\hline & Bank fixed effects & & $\checkmark$ & $\checkmark$ & $\checkmark$ & $\checkmark$ \\
\hline & $\begin{array}{l}\text { Group specific distance and popula- } \\
\text { tion effect }\end{array}$ & & & $\checkmark$ & $\checkmark$ & $\checkmark$ \\
\hline & Observations & $24,468,864$ & $24,468,864$ & $24,468,864$ & $24,468,864$ & $24,468,864$ \\
\hline
\end{tabular}

This table reports regression results from a fixed effects OLS analysis. The dependent variable is the share of deposits (in \%) a bank holds in county A. 'In(Distance in miles)' is the natural logarithm of the distance between a bank's home county and county A. Standard errors are robust, clustered at the bank level and reported in parentheses below. Significance
stars are: $* \mathrm{p}<0.10, * * \mathrm{p}<0.05,{ }^{* * *} \mathrm{p}<0.01$. 
Table 6: The impact of Diversification on Bank Risk - Instrumental Variables based on a Branching Deregulation-Gravity Model

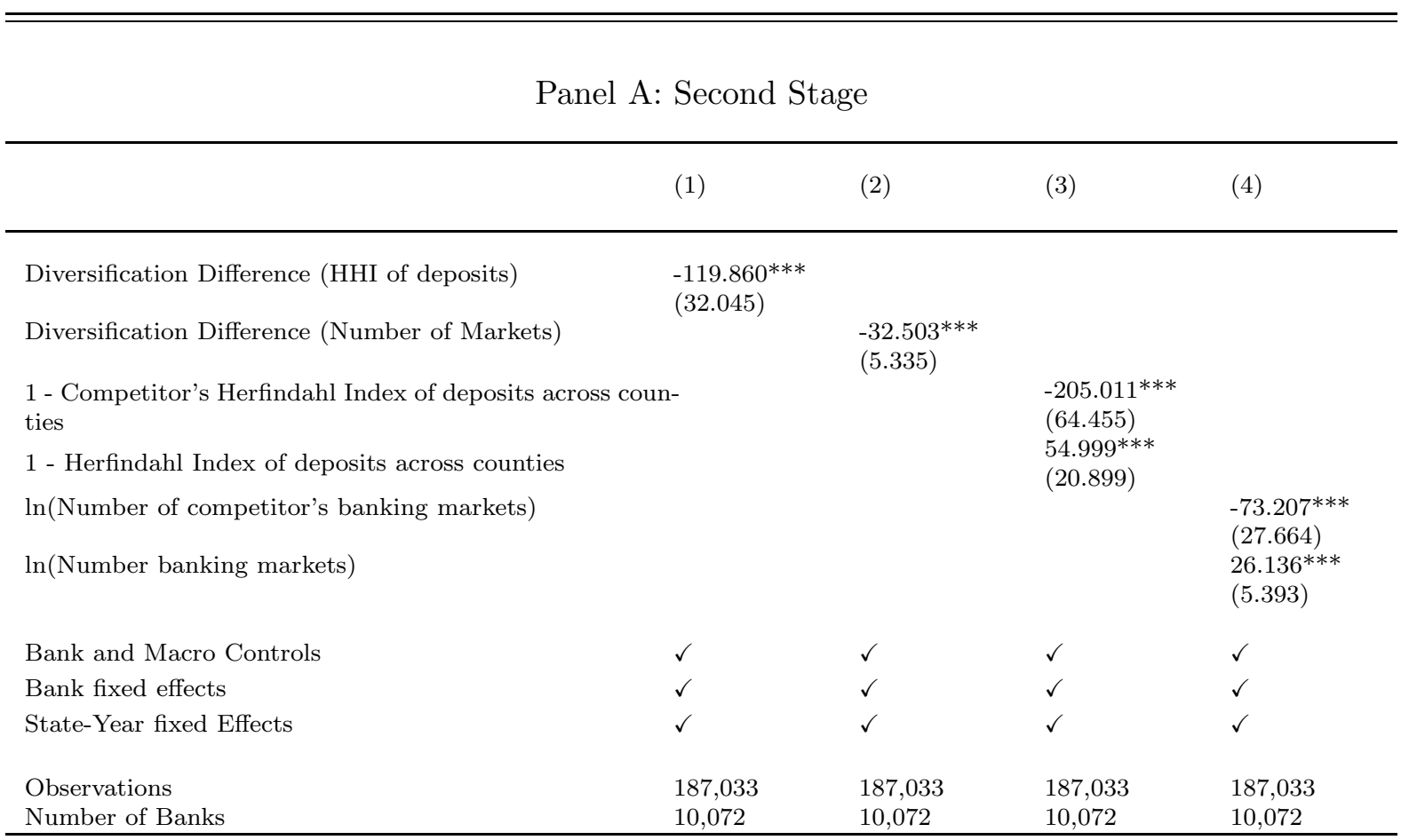

Excluded Instrument:

Number of banking markets (predicted)

Herfindahl Index of assets across counties (predicted)

$\checkmark$

Variables in Zero Stage:

$\ln ($ Distance $)$

(Intrastate Branching Deregulation) $* \ln ($ Distance $)$

(=1 if bank holds national bank charter prior to Branching Deregulation prior to Branching Deregulation $) * \ln ($ Distance $)$

\section{$-119.860 * * *$ \\ $32.045)$}

10,072
(27.664)

$26.136^{* *}$

This panel reports 2nd stage regression results from a bank and state-year fixed effects 2SLS analysis. The dependent variable is Inverse Z-Score, defined as (Standard Deviation of ROA)/(ROA + Capital-Asset-Ratio)*1000. The endogenous variables are: 'Diversification Difference (HHI Deposits)/ Diversification Difference (Number of Markets)', which is the relative difference between the a bank's deposit disper is the bank's competitors' average concentration of deposits across counties; 'ln(Number of banking markets)', which is the natura logarithm of the number of counties a bank has branches in; and 'ln(Number of competitor's banking markets)', which is the natura logarithm of a bank's competitors' average number of banking markets. The excluded instruments are from a gravity-deregulation model (see Table 5). Variables used in the gravity deregulation model are reported in the table. Standard errors are robust and reported in parentheses below. Significance stars are: ${ }^{*} \mathrm{p}<0.10,{ }^{* *} \mathrm{p}<0.05, * * * \mathrm{p}<0.01$ 


\section{A Mathematical Appendix}

\section{Preliminaries}

1.1 Probability of success $p(e)$ concave in $e$

$$
p^{\prime}(e)=\frac{\partial p}{\partial e}>0 \quad p^{\prime \prime}(e)=\frac{\partial^{2} p}{\partial e^{2}}<0
$$

\subsection{Sufficient condition to ensure equilibrium}

Suppsoe that:

$$
\frac{\partial \mu_{H}}{\partial A}-\frac{\partial \mu_{S}}{\partial A}+\beta^{2} \frac{\partial \mu_{H}^{2}}{\partial^{2} A}+\beta(1-\beta) \frac{\partial \mu_{S}^{2}}{\partial^{2} A} \leq 0 \quad \forall \beta \in[0,1]
$$

\subsection{Probability of becoming next CEO}

Let two loan officers of the same bank be denoted by $i$ and $j$. Loan officer $i$ will become the next $\mathrm{CEO}$ is his expected profit $E\left(\pi_{i}\right)$ net of the CEO's evaluation cost are higher than $j$ 's expected profits net of evaluation cost, ie.

$$
\begin{aligned}
\operatorname{pr}_{i}(i \text { becomes next CEO }) & =\operatorname{pr}\left(E\left(\pi_{i}\right)-c\left(\beta_{i}\right)>E\left(\pi_{j}\right)-c\left(\beta_{j}\right)\right) \\
& =\operatorname{pr}\left(E\left(\pi_{i}\right)-E\left(\pi_{j}\right)>c\left(\beta_{i}\right)-c\left(\beta_{j}\right)\right)
\end{aligned}
$$

Because the payoff for each borrower type is binomially distributed, a loan officer's loan portfolio is also normally distributed. Let the difference between loan officers' profits be denoted as $X=E\left(\pi_{i}\right)-E\left(\pi_{j}\right)$. X is also normally distributed with mean $\hat{\mu}$ and variance $\hat{\sigma^{2}}$. Furthermore, let the cumulative distribution function of $X$ be given by $F(X)$. Then the probability of loan officer $i$ to become the next 
CEO is given by

$$
\begin{aligned}
\operatorname{pr}_{i}(i \text { becomes next CEO }) & =\operatorname{pr}\left(X>c\left(\beta_{i}\right)-c\left(\beta_{j}\right)\right) \\
& =1-F\left(c\left(\beta_{i}\right)-c\left(\beta_{j}\right)\right)
\end{aligned}
$$

Taking the derivative of equation $\mathrm{A}-1$ with respect to $\beta_{i}$ yields:

$$
\frac{\partial p r_{i}}{\partial \beta_{i}}=-f\left(c\left(\beta_{i}\right)-c\left(\beta_{j}\right)\right) \times \frac{\partial c}{\partial \beta_{i}}>0
$$

Note that $f(\cdot)>0$ is the pdf, and therefore positive. Evaluation costs are supposed to decrease in $\beta$ which implies that $\frac{\partial p r_{i}}{\partial \beta_{i}}>0$.

\section{Proofs}

\section{$2.1 \quad$ Risk-Shifting}

The choice of effort by entrepreneurs is given by the following equation

$$
p^{\prime}(e)\left[R-r_{L}-\lambda\right]-e=0
$$

This implicit function gives the optimal choice of effort $\left(e^{*}\right)$ as a function of loan rates $\left(r_{L}\right)$ and collateral $(\lambda)$. Let $(\mathrm{A}-3)$ be denoted by the function $G\left(e, r_{L}\right)$. Applying the implicit function theorem shows that effort is decrease in the loan rate.

$$
\frac{\partial e^{*}}{\partial r_{L}}=-\frac{G_{r_{L}}}{G_{e}}=\frac{p^{2}}{p^{\prime}-e p^{\prime \prime}}<0
$$

Because the success probability $p(e)$ is decreasing in effort it can be shown that it is also decreasing in the loan rate:

$$
\frac{\partial p}{\partial r_{L}}=\frac{\partial p}{\partial e} \frac{\partial e}{\partial r_{L}}<0
$$




\subsection{Proposition 1: Differentiation}

Let the competing loan officer's choice of hard information borrowers be given by $\alpha$. Total supply of credit to hard information borrowers is therefore $\alpha+\beta_{i}$. A loan officer's optimal choice of $\beta$ is given by the following implicit function $H(\cdot)$ :

$$
H=(1-\gamma) \frac{\partial E\left(\pi_{i}\right)}{\partial A} \frac{\partial A}{\partial \beta_{i}}+\frac{\partial p r_{i}}{\partial \beta_{i}} \frac{2}{1+\rho} \bar{\Pi}=0
$$

Because $\beta_{i}^{*}$ maximizes a loan officer's expected profits, the second order condition is supposed to be negative at $\beta^{*}$, ie. $H_{\beta_{i}}<0$. The derivative of a loan officer's expected profit with respect to $\beta$ is given as

$$
\frac{\partial E\left(\pi_{i}\right)}{\partial \beta_{i}}=\beta_{i} \frac{\partial \mu_{H}}{\partial \beta_{i}}+\left(1-\beta_{i}\right) \frac{\partial \mu_{S}}{\partial \beta_{i}}+\mu_{H}-\mu_{S}
$$

where $\mu_{H} / \mu_{S}$ is the expected payoff from borrowing to hard/ soft information borrowers with $\mu_{H}=p_{H}(A)\left(r_{H}(A)+1\right)+\left(1-p_{H}\right) \lambda$ and $\mu_{S}=p_{S}(A)\left(r_{S}+1\right)$.

Using the implicit function theorem, we get

$$
\frac{\partial \beta_{i}}{\partial \alpha}=-\frac{H_{\alpha}}{H_{\beta_{i}}}
$$

because the second order condition $H_{\beta_{i}}$ is negative. Taking the partial derivative of (A-4) gives $H_{\alpha}=H_{\beta_{i}}-\frac{\mu_{H}}{\partial A}+\frac{\mu_{S}}{\partial A}$ and hence

$$
\frac{\partial \beta_{i}}{\partial \alpha}=-\frac{H_{\alpha}}{H_{\beta_{i}}}=\frac{\frac{\partial \mu_{H}}{\partial A}-\frac{\partial \mu_{S}}{\partial A}}{H_{\beta_{i}}}-1
$$




\subsection{Proposition 2: Effect of hierarchy on $\beta$}

Suppose a bank consists of $N$ branches. Then loan officer $i$ 's probability of becoming the next CEO is given by

$$
p r_{i}(i \text { becomes the next CEO })=(1-F)^{N-1}
$$

In the case of $N$ branches, a loan officer's optimal choice of $\beta$ is given by the following implicit function

$$
H=(1-\gamma) \frac{\partial E\left(\pi_{i}\right)}{\partial A} \frac{\partial A}{\partial \beta_{i}}+\frac{\partial p r_{i}}{\partial \beta_{i}} \frac{N}{1+\rho} \bar{\Pi}=0
$$

Applying the implicit function yields

$$
\frac{\partial \beta_{i}}{\partial N}=-\frac{H_{N}}{H_{\beta_{i}}} \propto H_{N}
$$

Because $H_{\beta_{i}}<0$ we have that the effect of $N$ on $\beta$ is proportional to $H_{N}$. Similar to before, we have that $\frac{\partial p r_{i}}{\partial \beta_{i}}>0$. Furthermore changes in $\beta$ have a higher effect on the probability of becoming the next CEO if the bank has more branches, ie.

$$
\frac{\partial^{2} p r_{i}}{\partial \beta \partial N}=\frac{\partial p r_{i}}{\partial \beta_{i}}\left[\frac{1}{N-1}+\ln \left(\frac{N-1}{N}\right)\right]>0
$$

and therefore $H_{N}$ becomes

$$
H_{N}=\frac{\partial^{2} p r_{i}}{\partial \beta \partial N} \frac{N}{1+\rho} \bar{\Pi}+\frac{\partial p r_{i}}{\partial \beta} \frac{1}{1+\rho} \bar{\Pi}>0
$$




\subsection{Proposition 3: Change in Loan Portfolio and Probability of Default}

A bank's PD is given as

$$
P D=\operatorname{Pr}(X<0)=\Phi\left(-\frac{\mu_{B}}{\sigma_{B}}\right)
$$

where $X$ characterizes a bank's loan portfolio and $\mu_{B} / \sigma_{B}$ is the loan portfolio's mean and standard deviation respectively, and $\Phi(\cdot)$ is the cdf of the standard normal distribution. Suppose two loan officers compete for borrowers in the market, and let their choice of hard information borrowers be given by $\beta$ and $\alpha$. Taking the total differential of this equation yields

$$
d P D=-\phi\left(-\frac{\mu_{B}}{\sigma_{B}}\right) \frac{\sigma_{B}\left(\frac{\partial \mu_{B}}{\partial \alpha} d \alpha+\frac{\partial \mu_{B}}{\partial \beta} d \beta\right)-\mu_{B}\left(\frac{\partial \sigma_{B}}{\partial \alpha} d \alpha+\frac{\partial \sigma_{B}}{\partial \beta} d \beta\right)}{\sigma_{B}^{2}}(-1)
$$

where $\phi$ is the standard normal pdf. Every loan officer optimally determines his choice of $\beta$. Because of symmetry, we have $\frac{\partial \mu_{B}}{\partial \alpha}=\frac{\partial \mu_{B}}{\partial \beta}=0$ :

$$
\frac{d P D}{d \beta}=-\phi\left(-\frac{\mu_{B}}{\sigma_{B}}\right) \frac{\mu_{B}}{\sigma_{B}^{2}}\left(\frac{\partial \sigma_{B}}{\partial \alpha} \frac{d \alpha}{d \beta}+\frac{\partial \sigma_{B}}{\partial \beta}\right)
$$

Note that $\phi\left(-\frac{\mu_{B}}{\sigma_{B}}\right) \frac{\mu_{B}}{\sigma_{B}^{2}}>0$. Due to symmetry, we have $\frac{\partial \sigma_{B}}{\partial \alpha}=\frac{\partial \sigma_{B}}{\partial \beta}$ and hence

$$
\frac{d P D}{d \beta} \propto \frac{\partial \sigma_{B}}{\partial \beta}\left(\frac{d \alpha}{d \beta}+1\right)
$$

The standard deviation of a bank's loan portfolio is given as $\sigma_{B}=\left[\beta^{2} \sigma_{H}^{2}+(1-\beta)^{2} \sigma_{S}^{2}\right]^{\frac{1}{2}}$. The derivative of the loan portfolio's standard deviation with respect to $\beta$ gives

$$
\frac{\partial \sigma_{B}}{\partial \beta}=\frac{1}{\sigma_{B}}\left[\beta \sigma_{H}^{2}\left(1+\varepsilon_{\sigma_{H}, \beta}\right)+(1-\beta) \sigma_{S}^{2}\left(\frac{1-\beta}{\beta} \varepsilon_{\sigma_{S}, \beta}-1\right)\right]
$$


where $\varepsilon_{\sigma_{S}, \beta} / \varepsilon_{\sigma_{H}, \beta}$ is the elasticity of soft/hard borrower's variance with respect to $\beta$. These elasticities are given as

$$
\begin{aligned}
\varepsilon_{\sigma_{H}, \beta} & =\beta \frac{\partial r_{H}}{\partial \beta}\left(\frac{1}{1+r_{H}-\lambda}+\frac{1}{2} \frac{\partial p_{H}}{\partial r_{H}} \frac{1-2 p_{H}}{\left(1-p_{H}\right) p_{H}}\right)<0 \\
\varepsilon_{\sigma_{S}, \beta} & =\beta \frac{\partial r_{S}}{\partial \beta}\left(\frac{1}{1+r_{S}}+\frac{1}{2} \frac{\partial p_{S}}{\partial r_{S}} \frac{1-2 p_{S}}{\left(1-p_{S}\right) p_{S}}\right)>0
\end{aligned}
$$

The partial derivative of $\sigma_{B}$ with respect to $\beta$ is continuous, monotone and defined for every $\beta$. Moreover, $\lim _{\beta \rightarrow 0} \frac{\partial \sigma_{B}}{\partial \beta}>0$, and $\lim _{\beta \rightarrow 1} \frac{\partial \sigma_{B}}{\partial \beta}<0$. 


\section{B Data Appendix}

\section{Sample Construction}

I compute Inverse Z-Score using semiannual information of profitability (Return on Assets) obtained from 'Call Reports'. In particular, I compute a 5 period moving average of the standard deviation of Return on Assets, where the computation of standard deviation for period $t$ uses information for periods $t-2$ to $t+2$. Because of this, I am not able to compute it for the first and last two periods. I then merge this information with 'Summary of Deposits' data which are available on an annual basis until 2006. This step limits the sample to annual bank observations for the years 1977 to 2006. Following previous research on intrastate branching deregulation, I drop the states of Delaware and South Dakota from the sample since the structure of the banking system in these two states was heavily affected by other laws, and it is not possible to isolate the effect of intrastate branching deregulation. Inverse Z-Score also exhibits very large volatility within the sample, and therefore I trim the sample with respect to the $1^{\text {st }}$ and $99^{\text {th }}$ percentile of Inverse Z-Score. This eliminates all outliers from the sample. In all regressions I restrict attention to banks that are active in only one state and exist before and after intrastate branching deregulation. Focusing on banks with branches in only one state allows me to better identify the effect of intrastate branching deregulation on risk as these banks were restricted in their geographic expansion.

\section{Variable Definitions}

Distress indicator I compute for each bank the annual change in its capital-asset ratio, and construct an indicator variable that takes on the value of one if a bank's capital-asset ratio drops in two consecutive years by more than 1 percentage point in each year. 
CAMEL-ratings Laeven et al. (2002) find that a higher ratio of loan loss reserves to capital, higher loan growth, lower net interest income to total income and lower return on assets are significantly correlated with bank failure. Following Laeven et al. (2002), I determine for each of these variables an indicator that takes on the value of one if the variable for a given bank is worse than that of $75 \%$ of all the sampled banks, and zero otherwise. For instance, if a bank's return on asset is lower than the 25th percentile, then this indicator is equal to one. Then, I sum these indicator variables and construct 'CAMEL'-ratings for each bank and year taking on values from 0 to 4 , where higher values indicate higher failure risk.

\section{Timing of Intrastate Branching Deregulation and Risk}

The identification of the effect of intrastate branching deregulation on risk rests on the assumption that the timing of deregulation is not affected by bank risk. This implies that states did not deregulate because of a certain level of bank risk in a state. To examine this graphically, I plot the year of intrastate branching deregulation against (1) the median Inverse Z-Score and (2) the average change of median Inverse Z-Score in each state, where I also condition on the aforementioned control variables. Figures (Figure B.1(b)) and (Figure B.1(a)) are presented in the appendix and suggest that there is no relationship between the timing of deregulation and the level of bank risk in a state.

Kroszner and Strahan (1999) estimate an accelerated failure time model to identify forces of deregulation in each state. They measure the stability of a state's banking system by the share of assets held by failing banks and do not find evidence that the level of bank (in)stability in a state is correlated with the timing of deregulation. I extend their methodology using my risk variables and test whether the median Inverse Z-Score or the median annual change in Inverse Z-Score in a state can predict the timing of deregulation (results available upon request). 


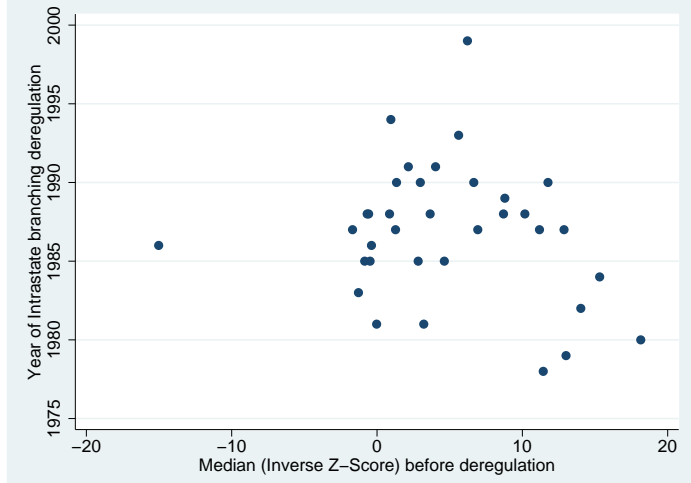

(a) Level of Bank Risk

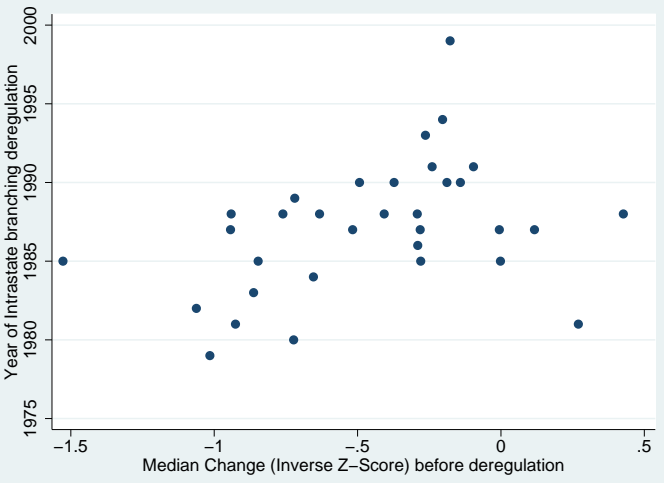

(b) Change of Bank Risk

Figure B.I: Timing of Deregulation and Bank Risk

Note: This figure plots the year of intrastate deregulation against the level/change of bank risk. Bank risk at the state level is measured by the median Inverse Z-score in that state. 
Table B.I: Variable Definitions

\begin{tabular}{|c|c|c|}
\hline Variable & Description & Source \\
\hline \multicolumn{3}{|l|}{ BANK } \\
\hline Net Income (Loss) & RIAD4340 & Call Reports \\
\hline Total Assets & RCFD2170 & Call Reports \\
\hline Equity & $\begin{array}{l}1976 \text { - 1989: RCFD3230 + RCFD3240 + RCFD3247 } \\
1990 \text { - 1993: RCFD3230 + RCFD3839 + RCFD3632 - RCFD0297 }\end{array}$ & Call Reports \\
\hline \multirow{3}{*}{ Total Loans } & 1994 - 2006: RCFD3230 + RCFD3839 + RCFD3632 + RCFD 8434 & \\
\hline & RCON1400 (1976 - 1984) & Call Reports \\
\hline & RCON1400 - RCON2165 (1984 - 2006) & Call Reports \\
\hline Return on Assets & 'Net Income (Loss)' divided by 'Total Assets' & \\
\hline Capital-Asset-Ratio & 'Equity' divided by 'Total Assets' & \\
\hline Loans-Assets-Ratio & 'Total Loans' divided by 'Total Assets' & \\
\hline Inverse Z-score & Standard Deviation of Return on Assets divided by (Return on Assets + Capital-Asset-Ratio) & \\
\hline $\operatorname{Ln}($ number of banking markets) & Natural log of number of markets in which a bank operate branches & Summary of Deposits \\
\hline $\begin{array}{l}1 \text { - Herfindahl Index of deposits across } \\
\text { counties }\end{array}$ & Sum of squared share of deposits for each bank in each county and year & Call Reports and Summary of Deposits \\
\hline$=1$ if bank part of bank holding company & RSSD9347 & Call Reports \\
\hline$=1$ if bank was member of Federal Reserve & RSSD9422 & Call Reports \\
\hline $\begin{array}{l}\text { System prior to Branching Deregulation } \\
=1 \text { if bank held Federal Charter prior to } \\
\text { Branching Deregulation }\end{array}$ & RSSD9347 & Call Reports \\
\hline \multicolumn{3}{|l|}{ BANKING MARKET } \\
\hline $\operatorname{Ln}($ number of banks in county) & Log of number of banking companies in county & Summary of Deposits \\
\hline $\operatorname{Ln}($ number of branches in county) & Log of total number of branches in county & Summary of Deposits \\
\hline Herfindahl Index of deposits in county & Sum of squared share of deposits for each banking company in county & Summary of Deposits \\
\hline Population per branch in county & County population estimates divided by number of branches in county & $\begin{array}{l}\text { Summary of Deposits and Local Area } \\
\text { Personal Income (BEA) }\end{array}$ \\
\hline Growth of personal income in county & Change in Personal County Income divided by last year's Personal County Income & Local Area Personal Income (BEA) \\
\hline \multicolumn{3}{|l|}{ Deregulation } \\
\hline$=1$ if Intrastate Branching Deregulation & Indicator whether states allow in-state branching & Amel and Liang (1992) \\
\hline
\end{tabular}


Table B.II: Timing of Intrastate Branching Deregulation

\begin{tabular}{|c|c|c|}
\hline State & Name & Year of Deregulation \\
\hline$\overline{\mathrm{AK}}$ & Alaska & 1960 \\
\hline $\mathrm{AL}$ & Alabama & 1981 \\
\hline $\mathrm{AR}$ & Arkansas & 1994 \\
\hline $\mathrm{CA}$ & California & 1960 \\
\hline $\mathrm{CO}$ & Colorado & 1991 \\
\hline $\mathrm{CT}$ & Connecticut & 1980 \\
\hline $\mathrm{DC}$ & District of Columbia & 1960 \\
\hline FL & Florida & 1988 \\
\hline GA & Georgia & 1983 \\
\hline HI & Hawaii & 1986 \\
\hline IA & Iowa & 1999 \\
\hline ID & Idaho & 1960 \\
\hline IL & Illinois & 1988 \\
\hline IN & Indiana & 1989 \\
\hline KS & Kansas & 1987 \\
\hline KY & Kentucky & 1990 \\
\hline LA & Louisiana & 1988 \\
\hline MA & Massachusetts & 1984 \\
\hline MD & Maryland & 1960 \\
\hline $\mathrm{ME}$ & Maine & 1975 \\
\hline MI & Michigan & 1987 \\
\hline $\mathrm{MN}$ & Minnesota & 1993 \\
\hline MO & Missouri & 1990 \\
\hline MS & Mississippi & 1986 \\
\hline MT & Montana & 1990 \\
\hline $\mathrm{NC}$ & North Carolina & 1960 \\
\hline ND & North Dakota & 1987 \\
\hline $\mathrm{NE}$ & Nebraska & 1985 \\
\hline $\mathrm{NH}$ & New Hampshire & 1987 \\
\hline NJ & New Jersey & 1977 \\
\hline NM & New Mexico & 1991 \\
\hline NV & Nevada & 1960 \\
\hline NY & New York & 1976 \\
\hline $\mathrm{OH}$ & Ohio & 1979 \\
\hline OK & Oklahoma & 1988 \\
\hline OR & Oregon & 1985 \\
\hline $\mathrm{PA}$ & Pennsylvania & 1982 \\
\hline RI & Rhode Island & 1960 \\
\hline $\mathrm{SC}$ & South Carolina & 1960 \\
\hline $\mathrm{TN}$ & Tennessee & 1985 \\
\hline $\mathrm{TX}$ & Texas & 1988 \\
\hline UT & Utah & 1981 \\
\hline VA & Virginia & 1978 \\
\hline VT & Vermont & 1970 \\
\hline WA & Washington & 1985 \\
\hline WI & Wisconsin & 1990 \\
\hline WV & West Virginia & 1987 \\
\hline WY & Wyoming & 1988 \\
\hline
\end{tabular}

